\title{
A FIELD GUIDE TO ANIMAL DAMAGE OF ALBERTA'S NATIVE TREES
}

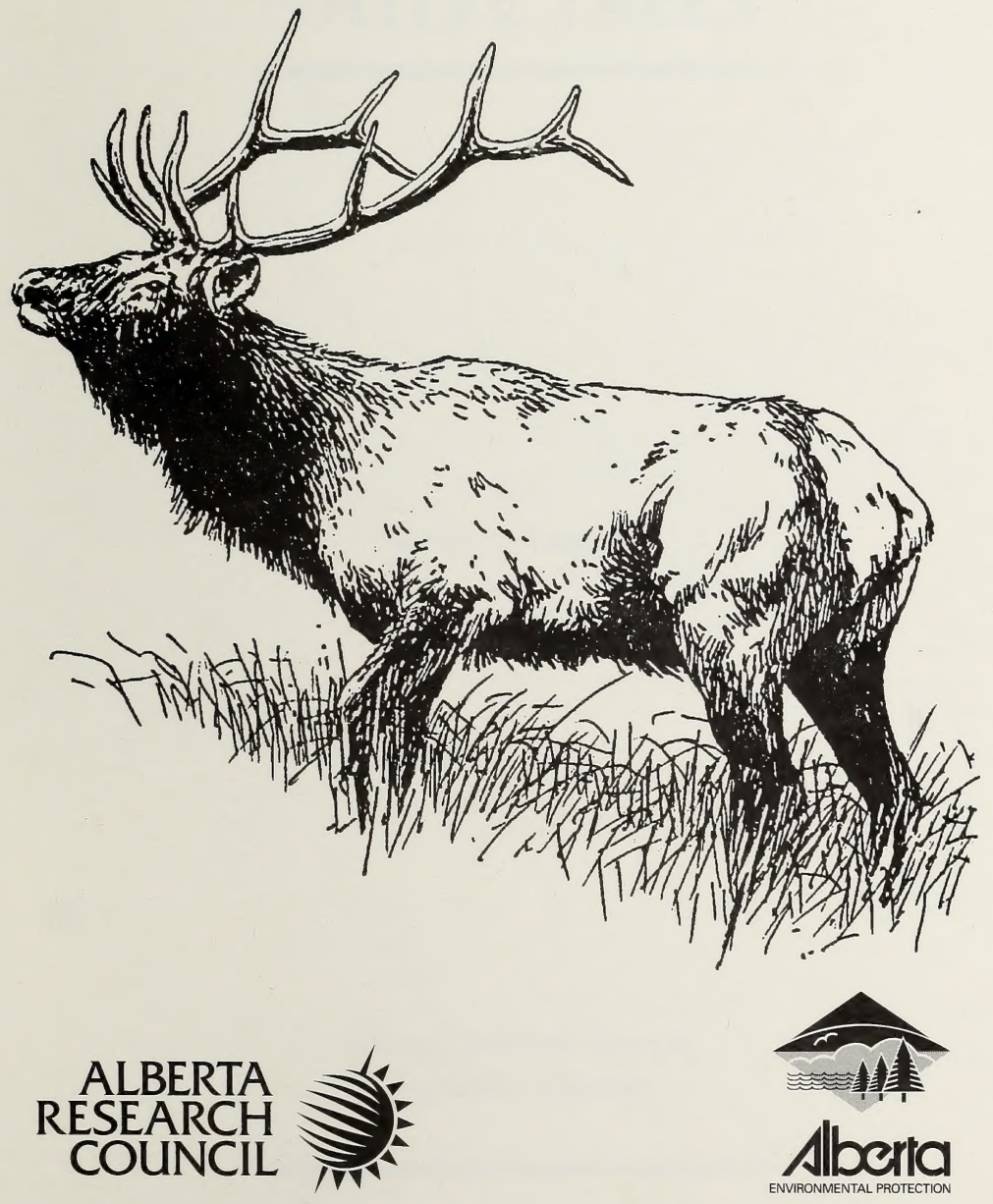





\title{
A FIELD GUIDE TO ANIMAL DAMAGE OF ALBERTA'S NATIVE TREES
}

\author{
By \\ Sheila A. Rangen \\ and \\ Laurence D. Roy
}

Alberta Research Council

Vegreville, Alberta 
ISBN 0-7732-5365-3

June, 1997

Additional copies of this publication are available from:

\author{
Alberta Environmental Protection \\ Information Center \\ Main floor, Bramalea Building \\ 9920 - 108 Street \\ Edmonton, Alberta, Canada \\ T5K 2M4
}

Phone: (403) 944-0313

OR

Alberta Research Council

Postal Bag 4000

Vegreville, Alberta, Canada

T9C $1 \mathrm{~T} 4$

Phone: (403) 632-8211

E-mail: aecinfo@aec.arc.ab.ca

This publication may be cited as:

Rangen, S.A., and L.D. Roy. 1997. A Field Guide to Animal Damage of Alberta's Native Trees. Alberta Research Council, Vegreville, AB. ARCV97-R1. 58pp. 


\section{ACKNOWLEDGEMENTS}

Funding for this project was provided by the Alberta Research Council, and Alberta Land and Forest Services, Forest Management Division.

J. Brad Stelfox, Dave McNabb, Melissa A. Todd, and Dave Patterson provided critical advice. We also thank Bruce Keith and Robert Pringle for design input and Greg Radstaak for assistance with figures.

The following sources are gratefully acknowledged for the use of their illustrations:

Dew Drop Arts and Crafts, Brenda Dew, Vegreville Alberta. (Figure 54)

Halfpenny, J. and E. Biesiot. 1986. A field guide to mammal tracking in North America. Johnson Books, Colorado. 164 pp. (Figures: 9-12, 19, 20, $25,33-35,58,71,72,81,87,94,95,101,102,107,108)$

Harestad, A.S., F.L. Bunnell, T.P. Sullivan, and L. Andrusiak. 1986. Key to injury of conifer trees by wildlife in British Columbia. Resource Branch, Ministry of Forests WHR-23. Victoria, British Columbia 38 pp. (Figures: 1, 5, 26, 30, 32, 63, 80, 86, 91, 96, 105, 106)

Murie, O.J. 1975. A field guide to animal tracks. Houghton Mifflin Company, Boston, New York. Copyright 1950 by Olaus J. Murie, Second Edition copyright $\odot 1974$ by Margaret E. Murie. Reprinted by permission of Houghton Mifflin Company. All rights reserved. 375 pp. (Figures: 21, 27, 37, 38, 40, 41, 52, 53, 55, 59, 60, 64, 65, 73, $83,89,103)$

Pattie, D.L. and R.S. Hoffman. 1992. Mammals of the North American parks and prairies. Edmonton, AB. 579 pp. (Figures: 15, 16, 23, 28, 43-46, $76-78,84,98,111)$

Radvanyi, A. 1971. Lodgepole pine seed depredation by small mammals in western Alberta. Forestry Science. 17:213-217. Reprinted from Forestry Science published by the Society of American Foresters, 5400 Grosvenor Lane, Bethesda, MD 20814-2198, Not for further reproduction. (Figures: 57, 68, 100) 
Schwartz, C.W. and E.R. Schwartz. 1981. The wild mammals of Missouri. University of Missouri Press, Columbia. $356 \mathrm{pp}$. Reprinted by permission of the University of Missouri Press. Copyright $@ 1981$ by the Curators of the University of Missouri (Figures: 6, 7, 17, 18, 24, $48,50,51,56,66,69,70,74,75,79,82,99,104$ )

Stelfox, J.B. Ed. 1993. Hoofed mammals of Alberta: their ecology, status, and management. Lone Pine Press, Edmonton, AB. 284 pp. (Figure: 36)

Stokes, D.W. and L.Q. Stokes. 1986. A guide to animal tracking and behavior. Little, Brown and Company, Boston. Copyright $\odot 1986$ by Donald W. Stokes and Lillian Q. Stokes; Illustrations Copyright (C) by Leslie Holt Merril, By Permission of Little, Brown and Company. 418 pp. (Figures: 13, 14, 31, 39, 42, 49, 61, 67, 88, 92, 93, 97, 109, 110)

Timm, R.M. Ed. 1983. Prevention and control of wildlife damage. Great Plains Agriculture Council Wildlife Resource Committee and Nebraska Cooperative Extension. Services, Institute Agriculture and National Resources, University of Nebraska, Lincoln. (Figures: 2, 3, 4, 85) 


\section{TABLE OF CONTENTS}

Page

Introduction

Key to Animal Injuries to Trees ................................................................ 3

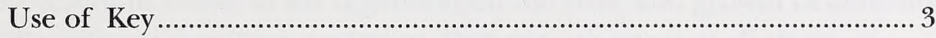

Bark Damage Key .......................................................................... 4

Stem, Root, and Branch Damage Key …....................................... 7

Cone, Bud, and Seed Damage Key ............................................. 9

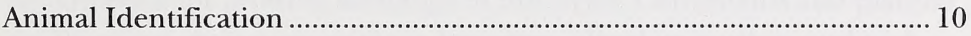

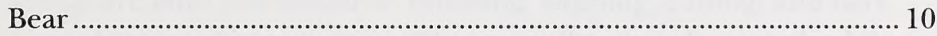

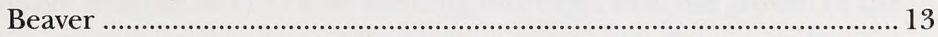

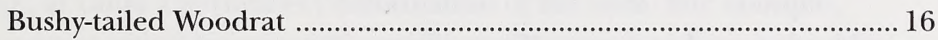

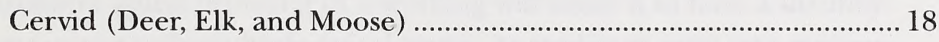

Domestic Livestock ........................................................................... 25

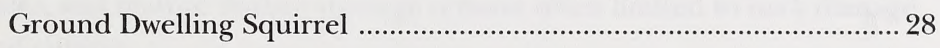

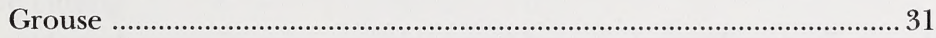

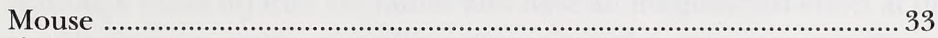

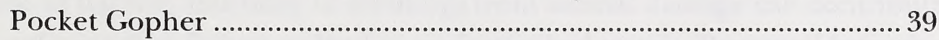

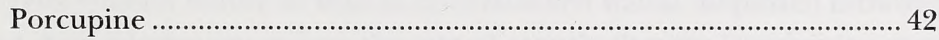

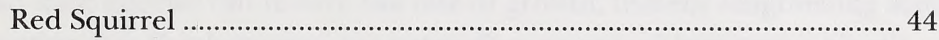

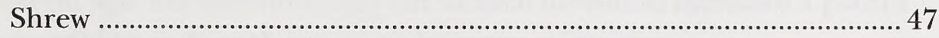

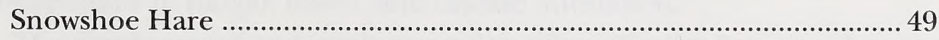

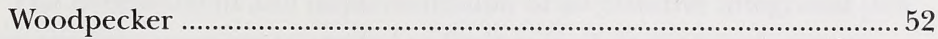

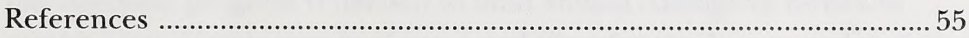


Digitized by the Internet Archive in 2016 


\section{INTRODUCTION}

Animal damage by wildlife and domestic livestock in Alberta forests can pose a serious threat to the regeneration, survival, and growth of deciduous and coniferous seedlings and trees. Damage can occur at all stages of seedling and stand development. Some wildlife species consume seed in a mature forest that is needed to regenerate the forest naturally or supply the seed needed for growing seedlings in nurseries. Germinants and planted seedlings are most susceptible to browsing, clipping, cutting, and bark damage that can either cause seedling mortality, slow the growth of the tree, or cause a permanent deformation of the stem. For example, successive apical browsing of a seedling will cause it to have a shrubby appearance with multiple apical stems. As seedlings grow into saplings, poles, and mature timber, damage is more often limited to bark damage and cutting.

Although many injuries are minor and have an insignificant effect at the time of harvest, mortality of seedlings from animal damage can contribute to reforestation failure or lead to understocked stands. Repeated browsing and stem injuries can reduce the rate of growth, thereby lengthening stand rotation age. Furthermore, any cut surface or wound increases a plant's susceptibility to fungal, insect, and disease infestation.

The development and implementation of an effective integrated pest management program is needed to limit animal damage in forests to ensure a sustainable supply of wood and fibre for the future, and to protect the often substantial investment of resources in site preparation, planting 
of seedlings, and tending of juvenile stands. An important first step in developing such a program is to accurately identify the species responsible for the damage. The objective of this manual is to provide a field guide for identifying the species of animal responsible for specific types of damage.

Identification of the species of animal causing damage can be confirmed by using a combination of diagnostic characteristics of injuries, tracks, scat, timing of damage, grazing history, geographical distribution, and other distinctive field signs of animals. Information on each of these attributes may be required to discriminate between certain species. For example, injury features may be all the information needed to discriminate browsing by horses from other domestic livestock and cervids (eg. deer, elk, moose), because horses have upper and lower incisors (front teeth) that create a clean, flat break unlike the torn, jagged one caused by cattle and cervids. However, when key characteristics are identical for more than one species such as deer and cattle that lack upper incisors, other information such as the timing of damage is required. In general the diet of cervids shift from forbs, grasses and leaves of woody plants during summer to twigs and bark of woody plants during winter. Since cattle are generally grazed in forested areas only during the summer, fresh browsing of seedlings recorded in early spring is attributable to cervids and fresh browsing recorded in early fall is attributable to cattle. Field sign such as tracks and scat would then be used to differentiate deer from moose or elk damage. 


\section{KEY TO ANIMAL INJURIES TO TREES}

\section{USE OF KEY}

Animals causing damage to trees and seedlings may be systematically identified using the Key to Animal Injuries to Trees and the Animal Identification section of this booklet. To use the key, select the most appropriate damage category (bark damage, stem, root and branch damage, or cone, bud and seed damage). Then select the best fit of two mutually exclusive statements and proceed to the corresponding key number and subsequently the next pair of statements. Continue in this manner until a species or group of species is identified.

The species or group of species selected from the key should then be verified using the Animal Identification section of the field guide. Other injury characteristics, tracks, scat, timing of damage, grazing history, habitat, and geographical distribution should correspond with the selected species or ultimately identify the species if more than one was listed in the key. If the species description fails to match the key selection an error was likely made during the keying process and the procedure must be repeated. 


\section{BARK DAMAGE KEY}

- removal of bark from the root, stem or branches of woody vegetation

- numerous tooth marks on and around the perimeter of the injury if gnawed

- tooth marks only on one side of the injury if stripped or scraped

- tooth marks absent if damage inflicted by claws, antlers, rubbing, or woodpecker activity

- width, depth, and orientation of tooth, claw, and antler marks and injury shape are characteristic

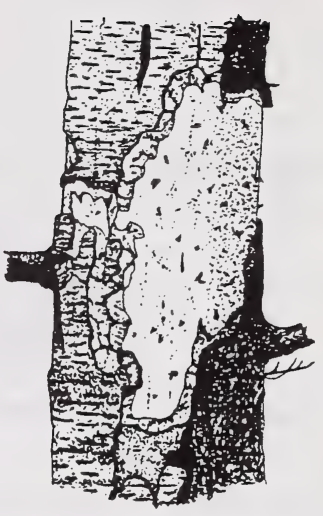

Figure 1 Bark damage on tree stem (gnawed).

1 bark damage on mature trees or larger saplings ......................................... 2

$1^{\prime} \quad$ bark damage on seedlings and smaller saplings ........................................ 12

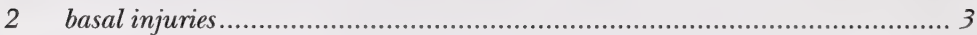

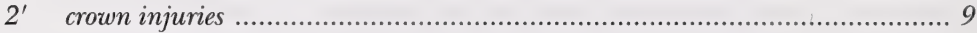

3 no distinct marks on wood or bark; bark pale and smooth around injury up to $1.3 \mathrm{~m}$ high; abrasion from rubbing .... DOMESTIC LNESTOCK (P. 25)

3' distinct or indistinct marks on wood or bark; bark normal around injury

4 evenly spaced rows of small $(0.5 \mathrm{~cm})$ circular injuries ............................................................. WOODPECKER (P. 52)

$4^{\prime} \quad$ irregular shaped injuries ............................................................... 5

5 hole excavated in wood; wood chips at base of tree ............... WOODPECKER (P. 52)

$5^{\prime}$ bark removed with little or no damage to wood 6 
vertical claw and tooth marks; large bark strips hanging

from coniferous trees and on the ground; exposed sapwood consumed

7 bark not gnawed, but scraped or stripped; vertical, shallow, close-spaced tooth marks (4 - $9 \mathrm{~mm}$ wide) on coniferous or deciduous trees

7' bark gnawed

8 distinct horizontal or diagonal tooth marks (4.5 $\mathrm{mm}$ wide)

on coniferous or deciduous trees PORCUPINE (P. 42)

$8^{\prime} \quad$ indistinct, fine tooth marks (1.6 - $2.5 \mathrm{~mm}$ wide); $1 \mathrm{~cm}$ wide bark strips peeled vertically or horizontally; discarded bark around base of coniferous trees

9 evenly spaced rows of small $(0.5 \mathrm{~cm})$ circular injuries; or rounded cavity entrances

9' irregular shaped injuries

10 sapwood with numerous tooth marks

$10^{\prime}$ sapwood with few tooth marks (1 $\mathrm{mm}$ wide); bark removed in patches; little bark at base of tree BUSHY-TAILED WOODRAT (P. 16)

11 horizontal or diagonal tooth marks (4.5 $\mathrm{mm}$ wide);

wound adjacent to a limb large enough to

support an animal PORCUPINE (P. 42)

11 narrow tooth marks (1.6 - $2.5 \mathrm{~mm}$ wide); $1 \mathrm{~cm}$ wide bark strips peeled vertically or horizontally on conifers; discarded bark around base of tree RED SQUIRREL (Р. 44)

12 tooth marks absent

$12^{\prime}$ tooth marks present

13 antler marks; coniferous or deciduous bark abraded or stripped and hanging from top and bottom of wound; broken branches; injuries at 0.4- $2 m$ above ground CERVID (P. 18)

$13^{\prime}$ antler or horn marks and shredded and/or abraded bark absent; nicks and scrapes on lower stem and branches.... CERVID AND DOMESTIC LIVESTOCK (P. 18 AND 25) 
14 indistinct tooth marks $0.1-1 \mathrm{~mm}$ wide; tooth marks

not uniform and occur at all angles; damage up to $30 \mathrm{~cm}$

high on coniferous and deciduous stems; hit and miss pattern;

discarded bark and peeled twigs in vicinity MOUSE (P. 33)

$14^{\prime}$ distinct tooth marks $>1 \mathrm{~mm}$ wide

15 tooth marks (1.6 mm wide); coniferous and deciduous

stems gnawed $\leq 2.5 \mathrm{~cm}$ in diameter; seedlings tilted at angle,

pull easily from ground, or turned brown;

exposed roots

POCKET GOPHER (P. 39)

$15^{\prime}$ tooth marks (1.6 - $3.2 \mathrm{~mm}$ wide) horizontal

and diagonal; coniferous and deciduous trees

usually $\leq 6 \mathrm{~cm}$ in diameter

SNOWSHOE HARE (P. 49)

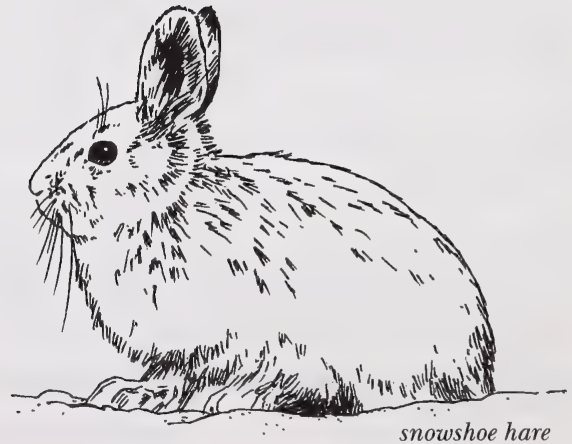




\section{STEM, ROOT, AND}

BRANCH DAMAGE KEY

\section{Browsing}

- feeding on small diameter woody vegetation by cervids and domestic livestock that leaves either a rough, jagged or a smooth perpendicular break with no tooth marks

- typical of species lacking upper front teeth and of horses

\section{Clipping}

- feeding on small diameter woody vegetation by rodents and hares that creates a smooth, angled, knifelike break with tooth marks

- head is tilted to one side to enable clipping

- diameter, angle, and sharpness of the cut stem are characteristic

- root clipping is typical of pocket gophers

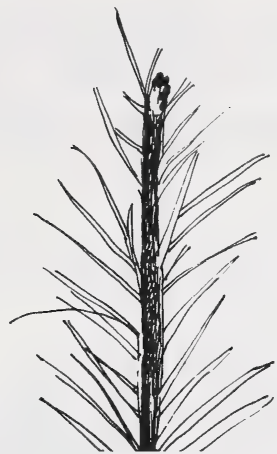

Figure 2 Seedling browsed by a cervid.

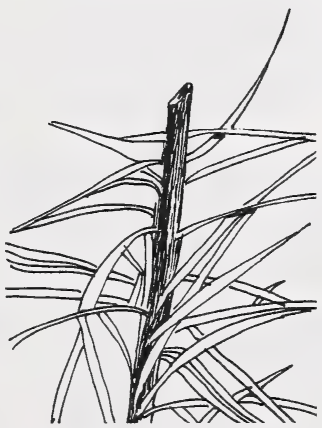

Figure 3 Seedling clipped by a snowshoe hare.

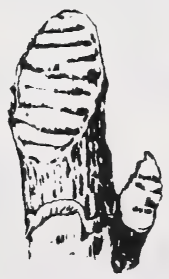

Figure 4 Tree and branch cut by a beaver. 
1 cutting of mature deciduous and coniferous trees;

trunk deeply notched leaving an hourglass cut or

cone-shaped stump

$1^{\prime} \quad$ cutting, browsing, or clipping of coniferous or deciduous

seedlings, saplings and mature tree branches

2 clean break ........................................................................ 3

$2^{\prime} \quad$ rough, jagged break; tooth marks absent ....................................... 9

3 root clipping

POCKET GOPHER (P. 39)

3' stem or branch damage

4 perpendicular break; no tooth marks

DOMESTIC LIVESTOCK (Р. 25)

$4^{\prime} \quad$ angled break; diagonal or horizontal tooth marks

5 distinct tooth marks

$5^{\prime} \quad$ indistinct tooth marks 8

6 tooth marks 1.6 - $3 \mathrm{~mm}$ wide; coniferous and deciduous seedlings and branches $\leq 6 \mathrm{~mm}$ in diameter. SNOWSHOE HARE (P. 49)

6' tooth marks $>3 \mathrm{~mm}$ wide

7 tooth marks (4 - $6 \mathrm{~mm}$ wide); deciduous and coniferous

seedlings, saplings, and branches $>6 \mathrm{~mm}$ in diameter;

peeled stems; conical stumps

$7^{\prime} \quad$ tooth marks (4.5 mm wide); coniferous and deciduous

branches $\leq 2.5 \mathrm{~cm}$ in diameter show parallel rows

of tooth marks; smaller twigs cleanly clipped

PORCUPINE (P. 42)

8 tooth marks (1.6-2.5 $\mathrm{mm}$ wide); cut edge of conifer

branch rasped not gouged by teeth; green conifer

branchlets lying on ground with cones and

buds removed.

RED SQUIRREL (P. 44)

$8^{\prime} \quad$ tooth marks (0.1 - $1 \mathrm{~mm}$ wide); cut edge is rasped with

multiple cut bites; shoots $\leq 6.2 \mathrm{~mm}$ in diameter....

9 fresh browsing of coniferous and deciduous trees incurred from late fall through the following spring .... CERVID (P. 18)

9' fresh browsing of coniferous and deciduous trees incurred during summer DOMESTIC LIVESTOCK (P. 25) 
- removal of cones from the tree crown to be eaten or cached and consumption of buds and dormant or germinating conifer seeds

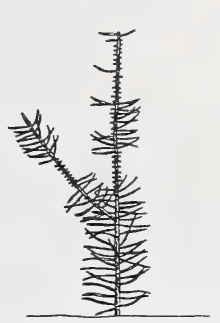

Figure 5 Bud damage caused by a grouse.

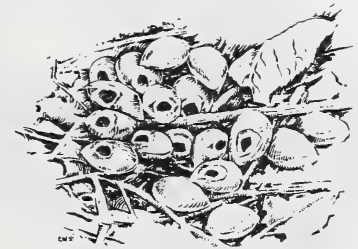

Figure 6 Seed damage caused by a mouse.

1 removal of buds from coniferous or deciduous stem 2

$1^{\prime}$ damage to cones and conifer seeds

2 tip of stem often damaged; most conifer needles cut bluntly around bud .................... CERVID AND DOMESTIC LIVESTOCK (P. 18 AND 25)

$2^{\prime} \quad$ bud cleanly extracted; individual conifer needles sometimes removed or clipped. GROUSE (P. 31)

3 seeds extracted from cones cut from conifers with or without branchlets attached; accumulation of cone scales on the ground. RED SQUIRREL (P. 44)

$3^{\prime}$ seeds extracted from uncut cones on the ground

4 one-quarter of seed coat removed at one end or along one edge; endosperm and embryo removed; scalloped appearance of cut edges; rejected seeds sport puncture holes MOUSE (P. 33)

$4^{\prime} \quad$ more than one-half of seed coat removed or split off. 5

5 one-half of seed coat removed from one flat side; endosperm and embryo removed; fine serrations along cut edges GROUND DWELLING SQUIRREL (P. 28)

$5^{\prime} \quad$ seed coat split almost in half; cut edges shattered and irregular SHREW (P. 47) 


\section{ANIMAL IDENTIFICATION}

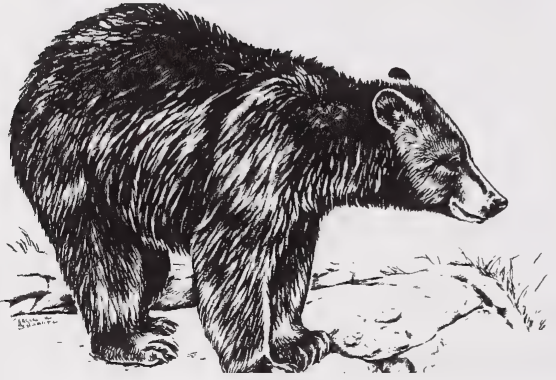

Bear

BLACK BEAR

(Ursus americanus)

GRIZZLY BEAR

(Ursus arctos)

Figure 7 Black bear.

\section{DAMAGE CHARACTERISTICS}

\section{Bark Damage}

- occurs primarily to large pine, trembling aspen and balsam poplar trees

- trees $15-38 \mathrm{~cm}$ in diameter often girdled

- bark stripped on the lower trunk of mature and pole-sized trees

- large strips of bark may litter the ground or be left hanging from the tree

- scraped area may be as large as $90 \mathrm{~cm}$ long by $30 \mathrm{~cm}$ wide

- exposed sapwood eaten leaving vertical incisor and canine tooth grooves, often as high as the bear can reach standing on its hind legs

- claw marks (usually diagonal but occasionally vertical or horizontal) on the sapwood may arise during feeding or during marking of a territory

- hair may be clinging to the tree

- typical in May, June, and July

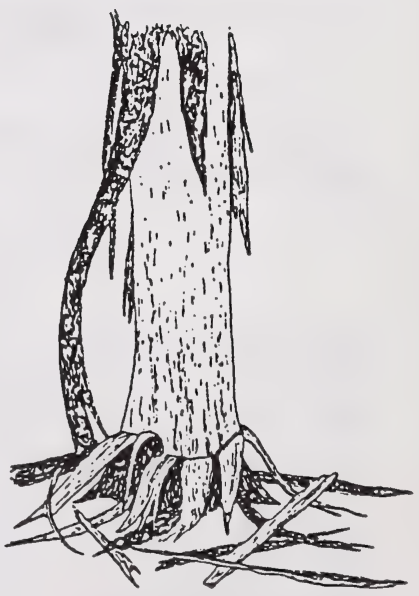

Figure 8 Bear damage to a mature tree. 


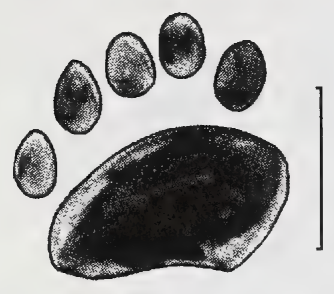

Figure 9 The toes of the front foot of the black bear form an arc over the intermediate pad. Claw marks, when showing, will have a length about equal to or less than the length of the toe pads. Scale is $5 \mathrm{~cm}$.

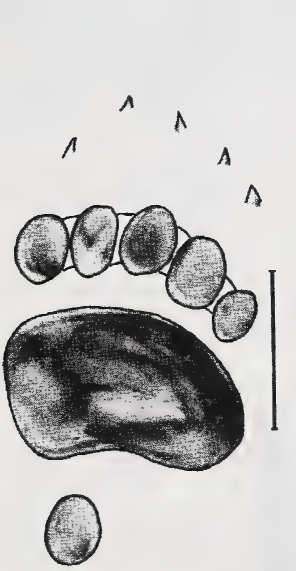

Figure 11 The toes of the front foot of the grizzly bear are crowded together and form a straight line across the intermediate pad. Claw marks about twice the length of the toe pads usually show. Scale is $10 \mathrm{~cm}$.

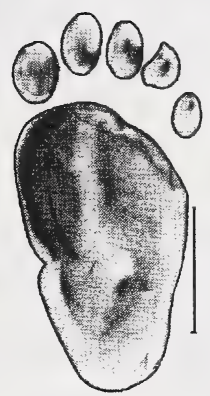

Figure 10 The hind foot. Scale is $5 \mathrm{~cm}$.
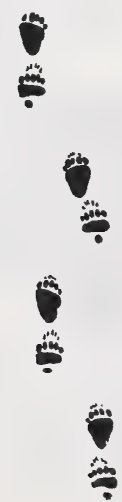

Figure 12 Bear walking gait. 


\section{Scat}

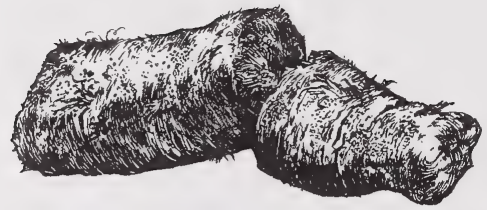

Figure 13 Scat are large and cylindrical with blunt ends. Segments are 5-7.6 cm long and 3-5 cm in diameter. Color may vary with food material ingested. A berry rich diet produces a blue semi-liquid scat with fruit seed; a grass, forb, and animal protein rich diet produces black scat with animal hair; a mast rich diet produces brown scat. Insect parts may also be observed in the droppings.

\section{Other}

- logs or stumps torn apart for insects

- excavated rodent burrows or anthills

- stripped berry patches
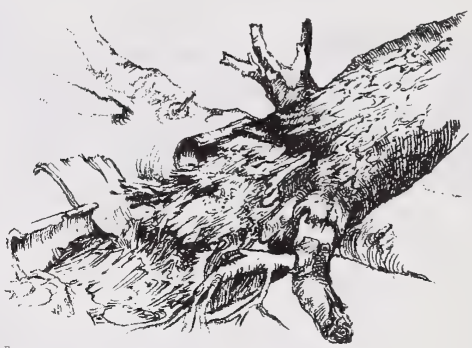

Figure 14 Rotted log torn apart by bear in search of insects.

\section{DISTRIBUTION}
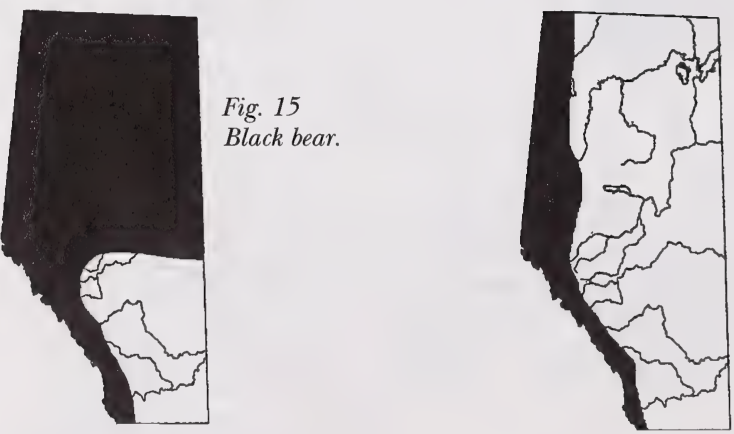

Fig. 16

Fig. 15

Black bear.

Grizzly bear. 


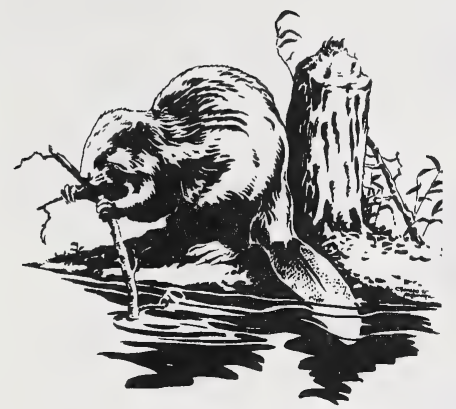

Figure 17 Beaver.

\section{BEAVER}

(Castor canadensis)

\section{DAMAGE CHARACTERISTICS}

\section{Cutting}

- trembling aspen, balsam poplar, birch, and willow preferred

- pine, spruce, and fir rarely felled

- trees up to $84 \mathrm{~cm}$ in diameter felled, though $10-15 \mathrm{~cm}$ in diameter preferred

- cone-shaped stumps 30-60 cm high

- partially cut trees with an hourglass shape

- broad chisel-like tooth marks 4- $6 \mathrm{~mm}$ wide

- close inspection reveals the fine space between the front two incisor teeth

- gnawing at an angle to the stem, whereas porcupine cutting may be parallel

- wood chips at the base of large trees

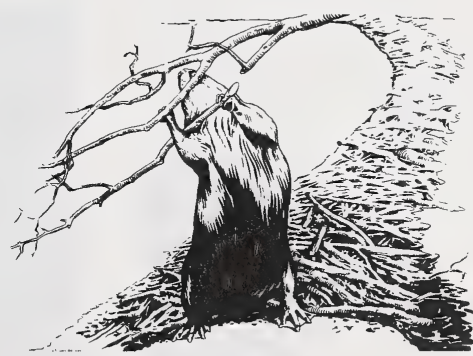

Figure 18 Beaver cutting branches from a tree.

- incidence of damage increases from spring through fall 


\section{FIELD SIGNS}

\section{Tracks}
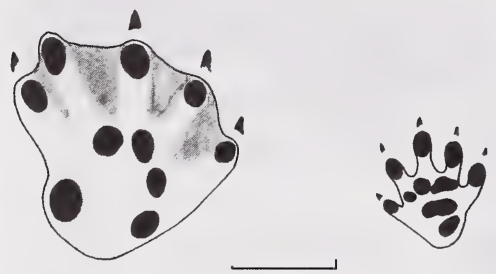

Figure 19 The hind foot shows webbing between the toes. The fifth toe may be visible on a clear front print. Claw marks are rarely present on the second inside toe of the hind foot. Scale is $5 \mathrm{~cm}$.

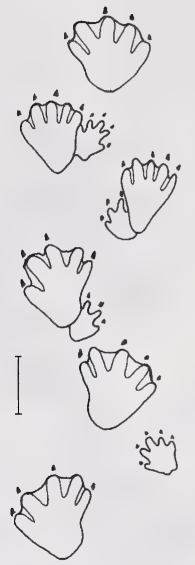

Figure 20 The front feet toein and may be hidden by the hind feet. Sometimes the tail may obliterate both prints. Scale is $15 \mathrm{~cm}$.

\section{Scat}

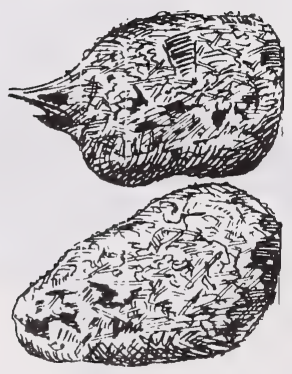

Figure 21 Oval pellets, $2.5-3.2 \mathrm{~cm}$ long and $1.9 \mathrm{~cm}$ in diameter are composed of coarse sawdust-like material. Scat are rarely detected as they are deposited in water. 


\section{Other}

- scattered stems with the bark removed in the cutting areas and adjacent waterways

- peeled stems $<3 \mathrm{~mm}$ in diameter may not bear tooth marks

- flooded areas, ponds, beaver lodges or dams

- trails connecting waterways to the area of damage

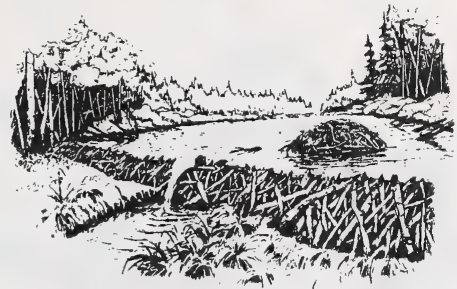

Figure 22 Beaver pond showing structure of a dam and lodge.

\section{DISTRIBUTION}

- distributed throughout Alberta

- in association with standing or running water

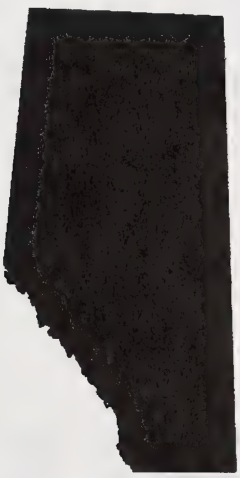

Figure 23 Beaver. 


\section{BUSHY-TAILED WOODRAT}

(Neotoma cinerea)

Figure 24 Bushy-tailed woodrat.

\section{DAMAGE CHARACTERISTICS}

\section{Bark Damage}

- short strips of bark removed in patches from the upper bole of conifer saplings and mature trees

- girdling at the crown may occur

- sapwood generally untouched, leaving a smooth surface with considerably fewer horizontal or diagonal tooth marks than the heavy gnawing of a porcupine or fine gnawing of a red squirrel

- tooth marks about $1 \mathrm{~mm}$ wide

- strips used for nest material; thus, less litter on the ground than from a red squirrel

- usually occurs in late winter and early spring

\section{FIELD SIGNS}

\section{Tracks}

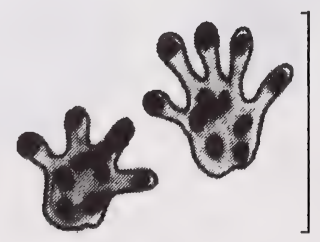

Figure 25 Footprints are roundish with extended heels. The four toes of the front feet and the five toes of the hind feet are bulbous. Scale is $2.5 \mathrm{~cm}$. 


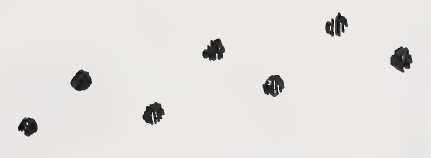

Figure 26 Diagonal bounding gait.

\section{Scat}

\section{Other}

- small branches clipped for food or nest material

- stick houses up to $0.5 \mathrm{~m}$ high by $1 \mathrm{~m}$ wide containing miscellaneous debris concealed in buildings, crevices, rock outcroppings, hollow logs or beneath stumps

- distinctive odour of scat and urine arises from the den area

\section{DISTRIBUTION}

Figure 28 Bushy-tailed woodrat.

Figure 27 Pellets are 9-15 $\mathrm{mm}$ long and 3-4 $\mathrm{mm}$ in diameter. Accumulation of fecal pellets, tarlike deposits of older scat, or white urine residues in the vicinity of the nest site. 


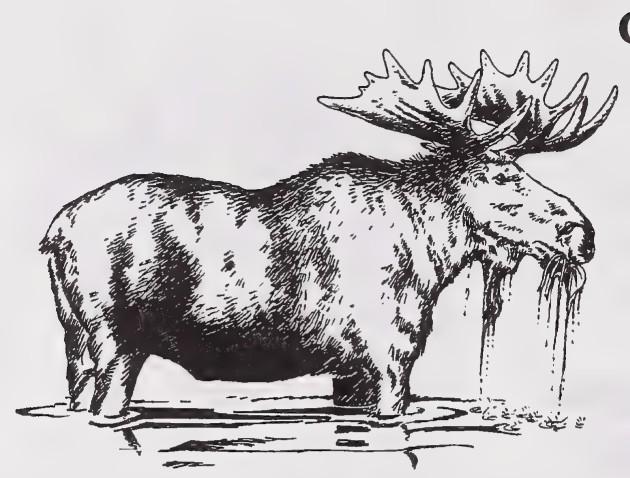

Cervid WHITE-TAILED DEER

(Odocoileus virginianus)

MULE DEER

(Odocoileus hemionus)

ELK (WAPITI)

(Cervus elaphus)

MOOSE

(Alces alces)

Figure 29 Moose.

\section{DAMAGE CHARACTERISTICS}

\section{Bark Damage}

\section{Antler Rubbing}

- occurs to coniferous and deciduous trees

- bark is abraded or stripped from the upper bole and branches of trees

- no tooth marks

- shredded bark hanging from the top and bottom of the bark wound

- smaller branches and saplings may be broken off

- traces of velvet may remain on the tree

- rubs occur 0.04 - 2 m above ground

- each tree used only once and there may be several rubs in one area

- height of damage may eliminate other mammals as the perpetrator

- rarely culminates in girdling

- occurs in late summer to late fall

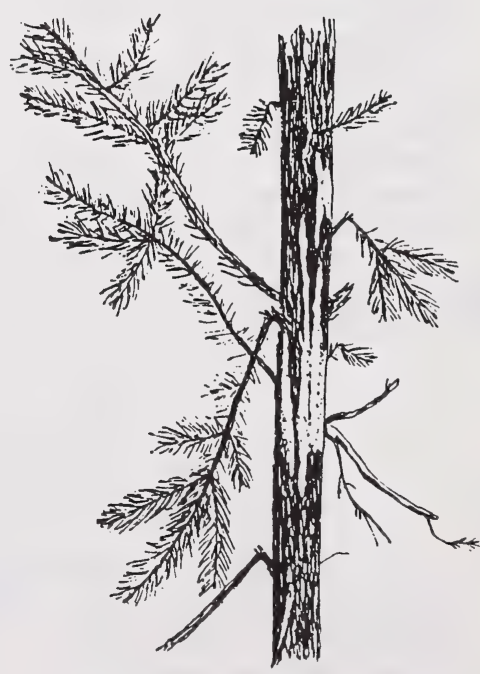

Figure 30 Antler rubbing damage to coniferous sapling. 


\section{Deer}

- prefer trees with smooth aromatic bark such as: pine, trembling aspen, balsam poplar, alder, and willow

- prefer saplings $1.6-2.5 \mathrm{~cm}$ diameter and $180 \mathrm{~cm}$ tall

- 5-year-old trees preferred, though occurs to trees $<15$ years old

- length of the injured area averages $25 \mathrm{~cm}$

- usually confined to $0.04-1.0 \mathrm{~m}$ above the ground

- finely shredded bark remains hanging on the tree

\section{Elk and Moose}

- prefer saplings $\geq 7.5 \mathrm{~cm}$ in diameter

- usually exceeds $1.0 \mathrm{~m}$ above ground

- abrade the tree trunk bare with little frayed bark remaining

- trees have more blunt and sporadic antler scores than those injured by deer

- may leave coarse, broken branches dangling

\section{Feeding}

- occurs to mature deciduous trees

- elk and moose commonly bark aspen

- bark is scraped or stripped, rather than gnawed, from upper bole using vertical upward sweeps of the lower front teeth

- bottom of the bark wound is sharply cut and the top is jagged because cervids lack upper teeth to nip the bark off

- stripped bark usually tapers to a narrow point where it breaks

- fresh bark may be stripped far above the point where cervids grasp the bark with front teeth

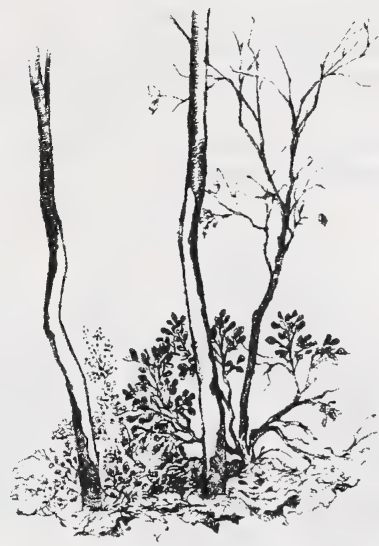

Figure 31 Antler rubbing damage to deciduous saplings.

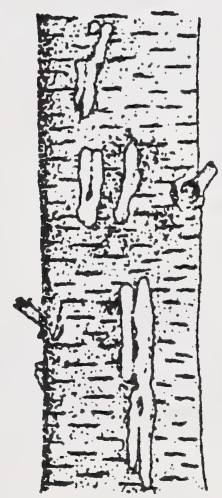

Figure 32 Cervid feeding on bark of deciduous tree. 
- new bark may be stripped immediately below the break on terminal and lateral stems during browsing in early to mid-spring

- shallow, close-spaced tooth marks remain in sapwood:

$$
\begin{gathered}
\text { deer - } 4 \mathrm{~mm} \text { wide } \\
\text { elk - } 6 \mathrm{~mm} \text { wide } \\
\text { moose - } 6-9 \mathrm{~mm} \text { wide }
\end{gathered}
$$

- elk and moose have rounder tooth marks with greater indentation than deer

- usually occurs from fall through spring

\section{Trampling}

- nicks and scrapes on tree stem or branches near base

- wounds usually smaller than those caused by cattle

- differentiate cervid from domestic livestock damage by other distinctive field signs in the vicinity and grazing history

\section{Browsing}

- occurs to pine, spruce, trembling aspen, balsam poplar, and paper birch

- moose prefer shrubs in plantations like willow, red-osier dogwood, and cranberry

- cut edges rough and jagged

- newly planted seedlings may be pulled from the ground during browsing

- in early spring, fresh browse points documented before the release of livestock will be winter damage resulting from cervids

- in summer, fresh browse points likely caused by livestock

- in fall, until the end of October when domestic stock is removed from a plantation, fresh browse points can either be caused by cervids or domestic livestock

\section{Bud Damage}

- buds nipped with a small part of the twig also removed

- broken ends of the stems, damage $\geq 40 \mathrm{~cm}$ from ground level, and the bluntended cropping of long needles surrounding the bud will differentiate cervid from grouse damage 


\section{FIELD SIGNS}

\section{Tracks}

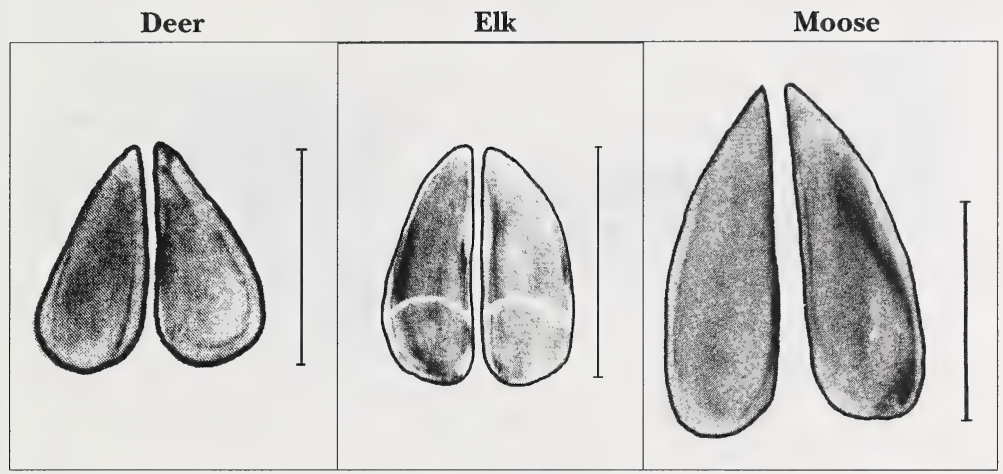

Figure 33 The outline of the print is heart-shaped. Dew claws are rarely visible except in a soft substrate. Scale is $5 \mathrm{~cm}$.
Figure 34 The print is broader and rounder than that of deer. Dew claws may be visible. Scale is $10 \mathrm{~cm}$.
Figure 35 The print is large and pointed with length far exceeding width. Dew claws are often visible. Scale is $10 \mathrm{~cm}$.

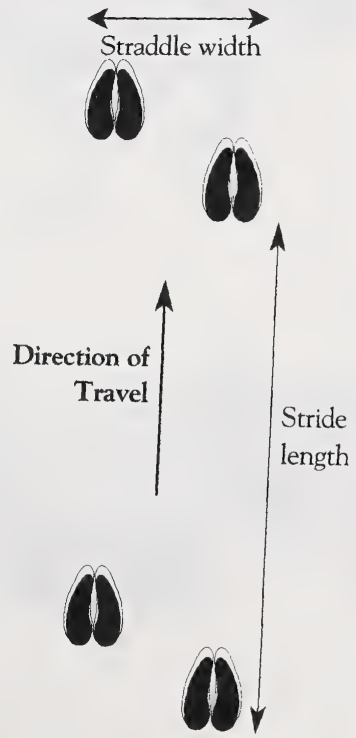

Front Hoof
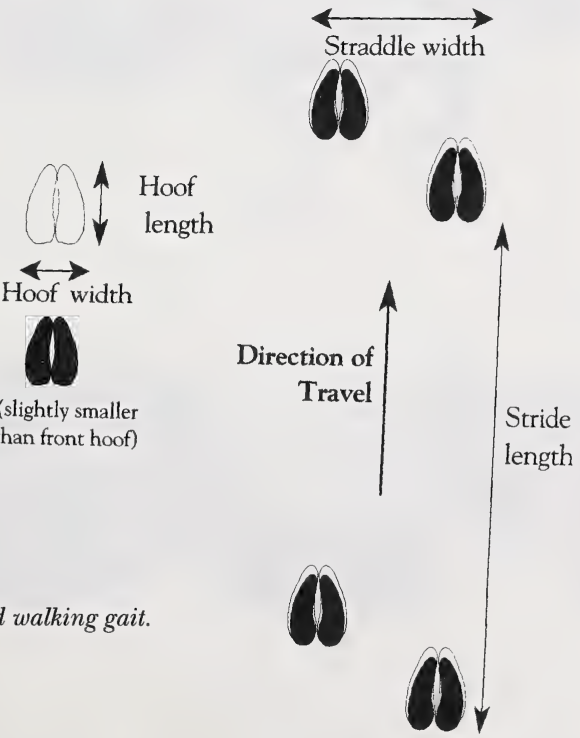

Figure 36 Cervid walking gait. 


\section{Scat}

\section{Winter}

Deer

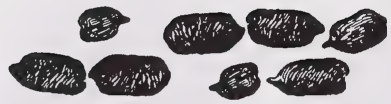

Figure 37 Pellets of adult deer are 10-22 $\mathrm{mm}$ long and $5-10 \mathrm{~mm}$ in diameter. One end is blunt and the other is more pointed. All cervids deposit scats in clumps of 20-30 pellets and pellet shape varies with diet.

Elk

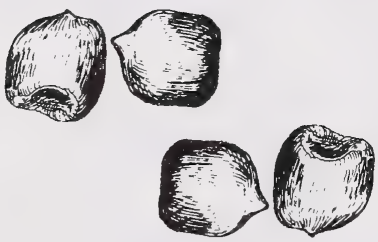

Figure 38 Pellets of adult elk are 18-25 $\mathrm{mm}$ long and 8-15 $\mathrm{mm}$ in diameter. One end has a dimple and the other has a nipple.

\section{Moose}

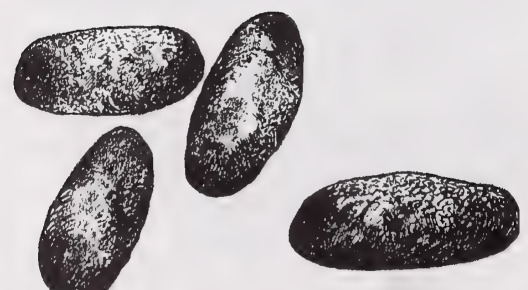

Figure 39 Pellets of adult moose are 20-30 $\mathrm{mm}$ long and 11-23 $\mathrm{mm}$ in diameter and round at both ends. Pellets have a very coarse texture. 


\section{Summer}

\section{Deer}

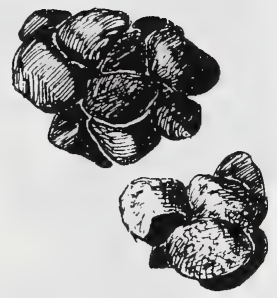

Figure 40 Individual, soft pellets clumped together. Clumps are $2.8-4.0 \mathrm{~cm}$ long and $2.3-$ $3.5 \mathrm{~cm}$ in diameter. All cervids may produce more than one individual clump.

\section{Elk}

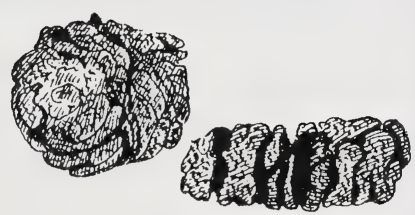

Figure 41 Individual, soft pellets clumped together. Clumps are 11.5-12 cm long and 4.6$9.8 \mathrm{~cm}$ in diameter.

\section{Moose}

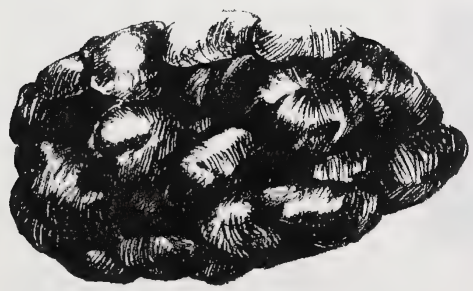

Figure 42 Pellets amalgamated in a soft mass. This clump is $6 \mathrm{~cm}$ long and $5 \mathrm{~cm}$ in diameter, but represents only a small portion of the total sample. 


\section{DISTRIBUTION}

\section{Deer}

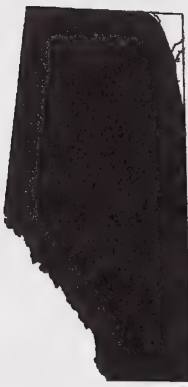

Figure 43 White-tailed deer.

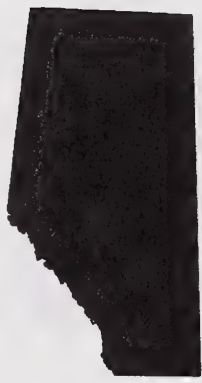

Figure 44 Mule deer.

Elk

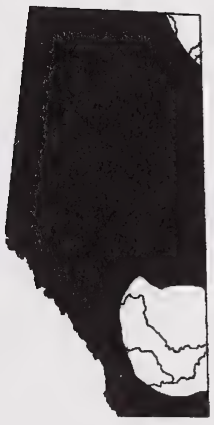

Figure 45 Elk.

\section{Moose}

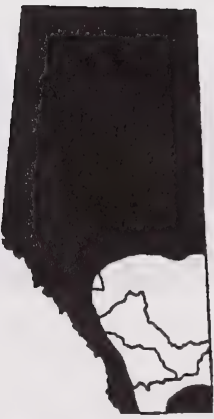

Figure 46 Moose. 


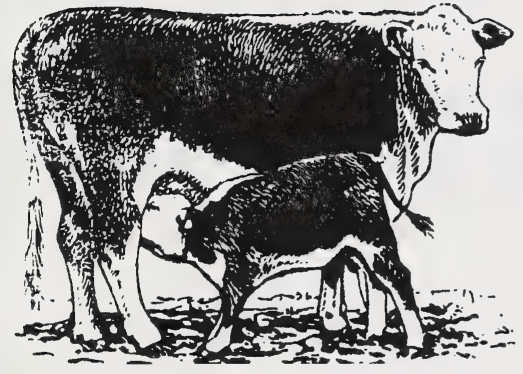

Figure 47 Cattle.
Domestic Livestock CATTLE

(Bos taurus)

GOAT

(Capra hircus)

HORSE

(Equus caballus)

\section{SHEEP}

(Ovis aries)

\section{DAMAGE CHARACTERISTICS}

\section{Bark Damage}

\section{Feeding}

- bark damage using front teeth occurs infrequently except when overgrazed

- bark may be scraped or stripped, similar to cervid (see P. 18)

\section{Trampling}

- nicks and scrapes are on the tree stem or branches near the base

- wounds usually larger than those caused by cervids

- presence of nearby tracks and scat will differentiate domestic livestock and cervid damage

\section{Rubbing}

- bark rubbed from base of large trees

- prefer coniferous trees but also rub deciduous trees

- rub trees at edge or in center of forest openings

- hair left on bark

\section{Browsing}

- cut edges jagged and torn as all bovids (cattle, sheep, and goats), like cervids, lack upper front teeth

- horses have upper front teeth that may create a cleanly nipped square break

- damage difficult to differentiate from cervids; thus, the presence of tracks and scat, grazing history of a particular area, and season are important

- fresh browsing in summer indicates domestic livestock whereas fresh browsing in late fall, winter and early spring during the absence of domestic livestock indicates cervids 


\section{FIELD SIGNS}

\section{Tracks}

\section{Cattle}

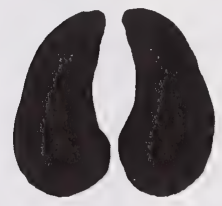

\section{Goat}

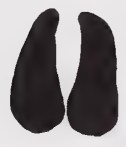

\section{Horse}

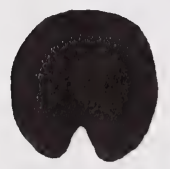

\section{Sheep}

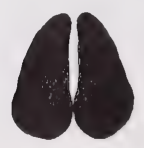

Figure 48 Adult tracks are 15-17 cm long with a round outline that is more pronounced if hooves are untrimmed. Between hoof halves the print outline is concave.

Figure 49 Adult prints are blocky and are 6.5$7.5 \mathrm{~cm}$ long. Tracks may be confused with sheep and deer; thus, habitat type and historical range use provide discriminating features.

Figure 50 Adult prints form a single semi-circle (15$17 \mathrm{~cm}$ long) with a triangular indentation in the back. Shod horse prints will show a distinct mark from the horseshoe.

Figure 51 Adult prints are wedge-shaped and are $7.5-9 \mathrm{~cm}$ long. Tracks may be confused with deer, bighorn sheep, and goats. Deer have a longer step length and are solitary or in small groups. Native sheep and goats are usually well scattered or in small groups. Habitat type and historical range use provide the best indicators of sheep presence. 


\section{Scat}

\section{Cattle}

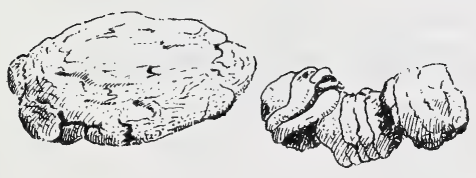

Figure 52 Scat may be brown, semi-soft patties, up to $30 \mathrm{~cm}$ in diameter, or firm layered chips, up to $15.5 \mathrm{~cm}$ long.

\section{Goat}

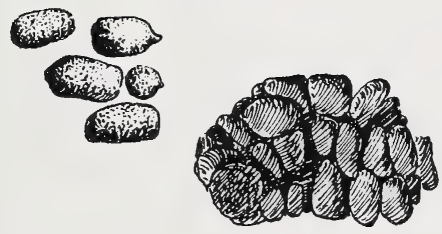

Figure 53 Scat resemble those of mountain goats, deer, and sheep; but, pellets tend to be smaller and more layered. Pellets are $0.8-1.8 \mathrm{~cm}$ long and $0.5-1.3 \mathrm{~cm}$ in diameter and may be amalgamated in summer. Similar to sheep, historical range use provides a clue to species identification.

\section{Horse}
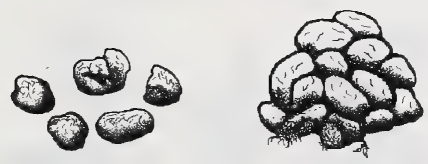

Figure 54 Scat are light to dark brown and contain coarse undigested fibres. Pellets are rounded, 4-6 cm in diameter, and may be amalgamated in summer.

\section{Sheep}

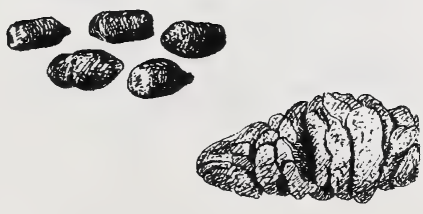

Figure 55 Scat resemble those of mountain sheep and goats. Dry pellets are spherical or elongated with either two rounded ends or one rounded and one pointed end. Moist pellets may be concave on one side. Individual pellets are 0.8$1.8 \mathrm{~cm}$ long and $0.5-1.3 \mathrm{~cm}$ in diameter and may be amalgamated in summer. 


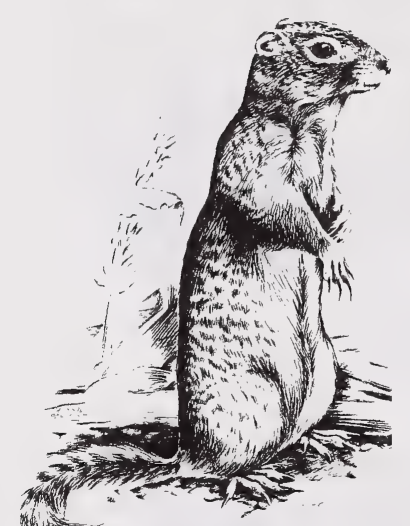

\section{Ground Dwelling Squirrel CHIPMUNK}

(Tamias spp.)

GROUND SQUIRREL

(Spermophilus spp.)

Figure 56 Ground squirrel.

\section{DAMAGE CHARACTERISTICS}

\section{Seed Damage}

- newly germinated coniferous seedlings clipped

- endosperm and embryo removed from tree seeds and eaten or cached

- accumulation of open seed hulls

- unlike mice, Tamias spp., remove about half of a seed coat from one flat side of the seed

- cut edges have fine serrations with no wide indentations as observed with mice

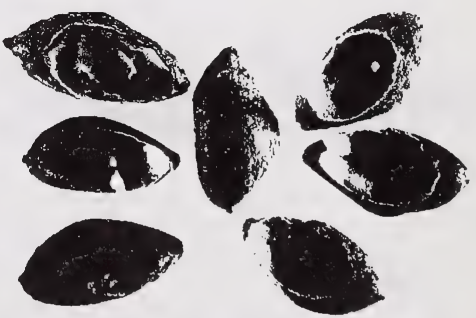

Figure 57 Seed damage caused by a chipmunk. 


\section{FIELD SIGNS}

\section{Tracks}

Figure 58 The gait of grounddwelling squirrels shows a diagonal front feet pattern (note diagonal line drawn through front feet tracks) with four toes on the front feet and five toes on the hind feet. Ground squirrels have front feet $1.6 \mathrm{~cm}$ and hind feet $2.5 \mathrm{~cm}$ long. Chipmunks have front feet $1 \mathrm{~cm}$ and hind feet $1.6 \mathrm{~cm}$ long.

\section{Scat}

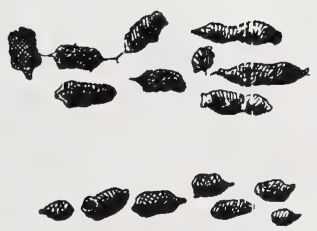

Figure 59 Chipmunk scat are rarely found above ground and usually deposited at random. Pellets may be found infrequently on logs or stumps where they perch. Scats are only slighter larger than that of voles and mice with a length of 5-13 mm and a diameter of 2-3 $\mathrm{mm}$.

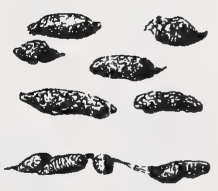

Figure 60 Ground squirrel scat, 9-16 $\mathrm{mm}$ long and 4-5.5 $\mathrm{mm}$ in diameter, are generally connected by tails. Pellets may be found outside the burrow entrance or in the tunnel system. 


\section{Other}

- terminal buds removed

- burrow systems for ground squirrels

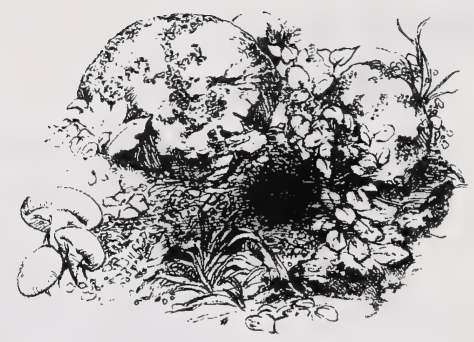

Figure 61 Ground squirrel burrow.

\section{DISTRIBUTION}

- 3 species of chipmunk are distributed throughout Alberta

- 5 species of ground squirrel are distributed throughout central and southern Alberta

- for species distribution maps see Pattie and Hoffman 1992 


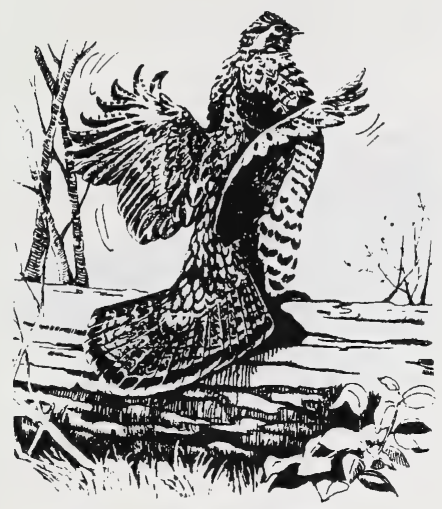

Figure 62 Ruffed grouse.
Grouse BLUE GROUSE

(Dendragapus obscurus) RUFFED GROUSE (Bonasa umbellus) SHARP-TAILED GROUSE

(Tympanuchus phasianellus) SPRUCE GROUSE (Dendragapus canadensis)

\section{DAMAGE CHARACTERISTICS \\ Bud Damage}

- ruffed and sharp-tailed grouse prefer trembling aspen, balsam poplar, and willow buds

- spruce and blue grouse prefer spruce and pine needles

- trees often show selective feeding of buds only

- bud is cleanly removed with little breakage

- occasionally twigs may be broken during bud removal leaving bark fibres hanging

- individual conifer needles, not twigs, are nipped

- grouse usually stand on the ground or on another limb while feeding and generally do not jump from the ground for buds just out of reach

- buds consumed on branches beyond the reach of grouse, that are not stout enough for the bird to stand on, may be due to cervids or domestic livestock

- occurs in winter

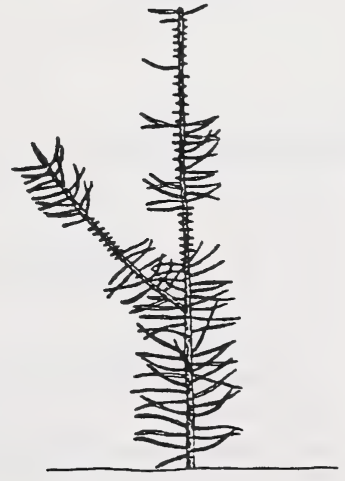

Figure 63 Bud damage caused by grouse; needles removed. 


\section{FIELD SIGNS}

\section{Tracks}

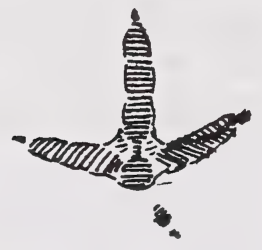

\section{Scat}

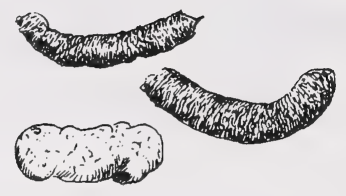

\section{DISTRIBUTION}

- grouse are distributed throughout Alberta

- blue grouse are associated with higher elevation montane and foothills regions

- ruffed and spruce grouse are distributed throughout all forested regions of Alberta

- sharp-tailed grouse are distributed throughout Alberta except at high elevations

- for more detailed distribution maps consult Johnsgard 1973
Figure 64 Prints have three long toes with one short toe pointing the opposite direction. Track length is $5-6.4 \mathrm{~cm}$.
Figure 65 Pellets are firm, curved cylinders (2.5-3.5 cm long), though they may be soft in summer. Scats are deposited in clusters, often times on logs or rocks. 


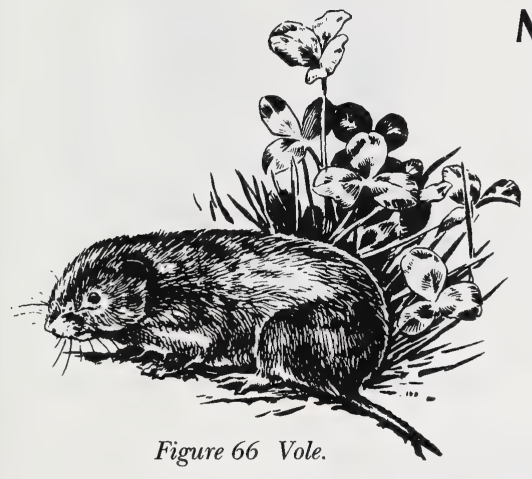

\section{Mouse} DEER MOUSE

(Peromyscus maniculatus) MEADOW VOLE (Microtus pennsylvanicus) RED-BACKED VOLE (Clethrionomys gapperi)

\section{DAMAGE CHARACTERISTICS}

\section{Bark Damage}

- occurs to coniferous and deciduous trees

- tree diameters $0.1-19 \mathrm{~cm}$ preferred

- incidence of damage increases with decreasing height

- injuries occur to trees $\leq 16 \mathrm{~m}$ high

- bark is gnawed on roots and low branches at the root collar or the snow surface

- barking may extend up the bole to over $120 \mathrm{~cm}$, because of snow cover, though it is typically $\leq 30 \mathrm{~cm}$

- discarded bark and small piles of peeled twigs $7.5-10.2 \mathrm{~cm}$ long may lie near the injured tree

- succulent inner bark or phloem is consumed

- selection of stems and branches displays a hit-or-miss pattern

- tree roots may be exposed and peeled 
- girdling may occur

- tooth marks not prominent and give the gnawed surface a fuzzy, roughened appearance

- close inspection may reveal tooth marks $0.1-1 \mathrm{~mm}$ wide,

0.1-1.6+ mm deep, and 0.1-

$9.5 \mathrm{~mm}$ long in irregular patches

- tooth marks at all angles and not uniform

- trees infected with rusts (Cronartium spp.) may be more susceptible to damage

- typically occurs in winter under snow cover and occasionally in summer under dense, matted vegetation

\section{Clipping}

- occurs to coniferous and deciduous seedlings

- occurs to seedlings and shoots $\leq 6.2 \mathrm{~mm}$ diameter

- cut rougher than other larger rodents as many bites are needed to sever the stem

- tiny stumps similar to beaver cutting may remain

\section{Seed Damage}

- germinating coniferous seedlings dug up and the cotyledon clipped

- seeds opened at the micropyle end

- about one-quarter of the seed coat eaten either at one end or along one edge of the seed

- chewed edges have a scalloped appearance

- endosperm and embryo removed

- empty seeds that are rejected may have a puncture hole

- seed hulls lying on the ground

- no distinct tooth marks

- occurs primarily in summer

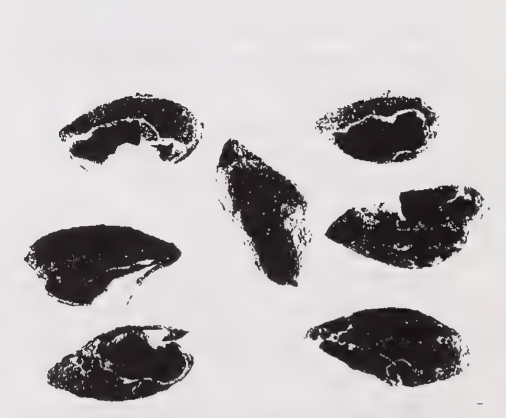

Figure 68 Seed damage caused by deer mouse.

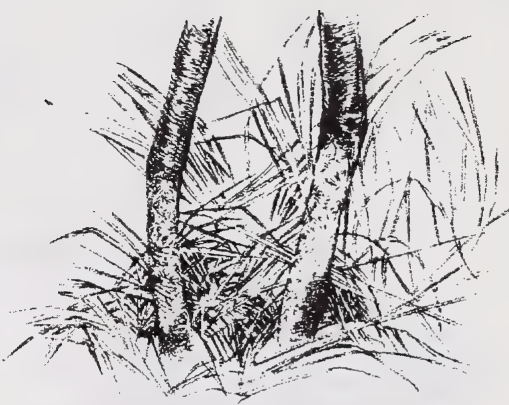

Figure 67 Bark damage caused by voles. 


\section{FIELD SIGNS}

\section{Tracks}
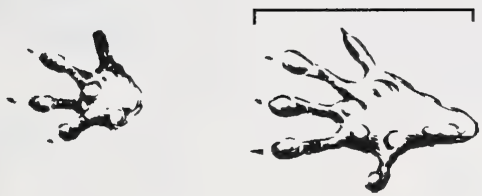

Figure 69 The front foot and the hind foot of the deer mouse have four and five toes, respectively. Scale is $19 \mathrm{~mm}$.
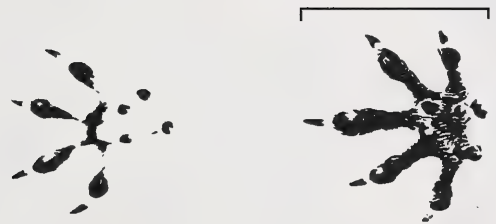

Figure 70 The front foot of a vole has four toes and the hind foot has five toes. A print outline may not be present if only pads register. Scale is $12 \mathrm{~mm}$. 
$: 0$

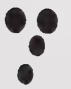

$\because 1$

4

8
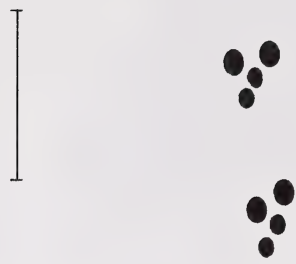

Figure 71 Deer mice when hopping may leave a tail drag (left) or may hold their tails vertically, leaving none. Scale is $15 \mathrm{~cm}$.

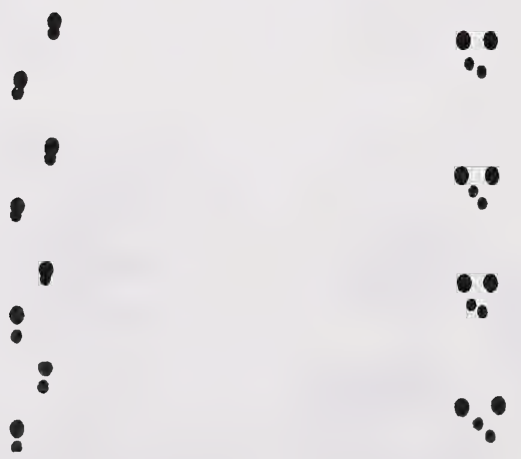

Figure 72 Walking gait of voles where the hind foot oversteps the front foot (right) and diagonal hop where a tail drag rarely shows. 


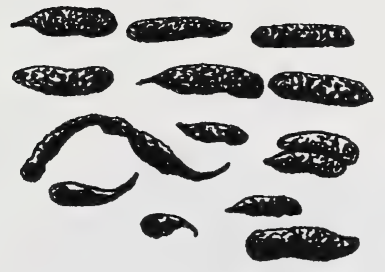

Figure 73 Scats are cylindrical with rounded ends (3-5 $\mathrm{mm}$ long). Deer mouse scat cannot be distinguished from vole scat, except by the location in runways and tunnels. In contrast to deer mice, vole scat may also form a clump due to urine deposition and are found outside of the nests. Droppings may be mixed with fruit or seed.

\section{Other}

\section{Deer Mouse}

- most common nocturnal mammalian seed eater

- bark damage and clipping extremely rare

- clusters of fruit (eg. rose) clipped and individual fruit opened at the top with the seeds removed

- no surface runways in ground vegetation

- small burrow holes in the ground are more common than above ground nests

- nests above ground $(15 \mathrm{~cm}$ in diameter) are usually under a root or log

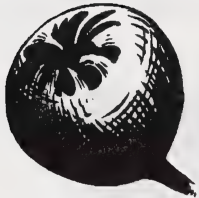

Figure 74 Rose hip opened at the top with seeds removed. 


\section{Vole}

- well-traveled runways and abandoned winter nests (15-20 $\mathrm{cm}$ in diameter) constructed in tufts of grass

- surface runways, $2.5-5 \mathrm{~cm}$ wide, contain clipped stems and leaves of vegetation cut from the sides and bottom of the tunnel

- runways contain scat, particularly at intersections

- tunnel openings $(3.8 \mathrm{~cm}$ in diameter) leading to underground summer nests may be detected by probing for holes

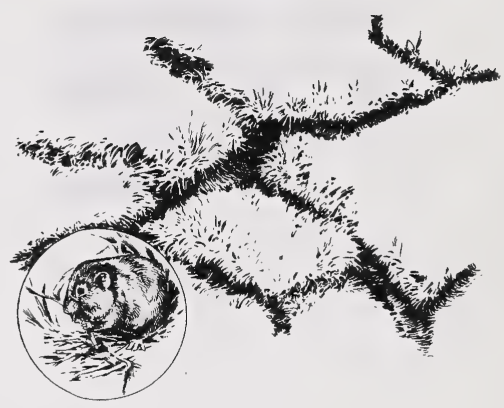

Figure 75 Vole runways in dense grass vegetation.

\section{DISTRIBUTION}

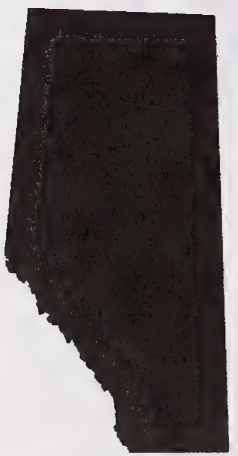

Figure 76 Deer mouse.
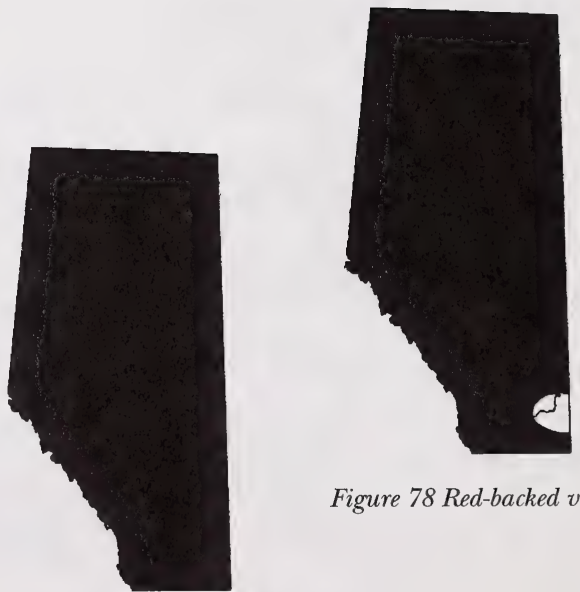

Figure 78 Red-backed vole.

Figure 77 Meadow vole. 

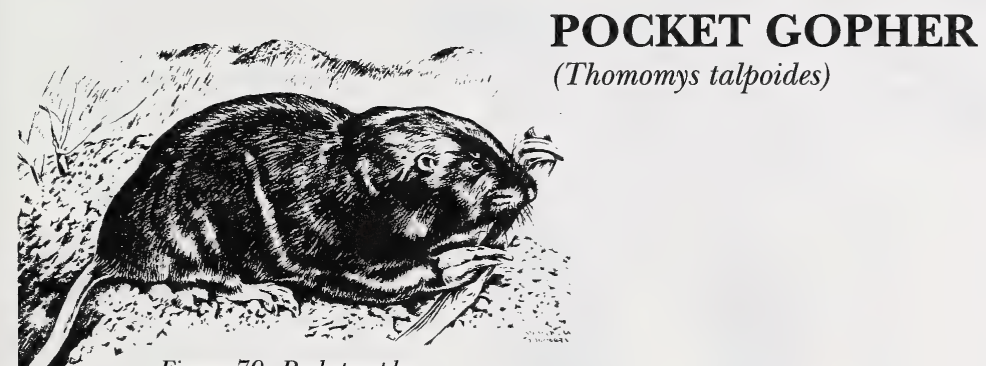

(Thomomys talpoides)

Figure 79 Pocket gopher.

\section{DAMAGE CHARACTERISTICS Bark Damage}

- occurs to small and large coniferous and deciduous trees, commonly lodgepole pine and trembling aspen

- stem barking and girdling below and near ground level

- injuries may extend upwards to $2 \mathrm{~m}$ with deep snow cover

- tooth marks about $1.6 \mathrm{~mm}$ wide

- occurs primarily in winter under snow cover

\section{Clipping}

- occurs to coniferous and deciduous seedlings

- root pruning

- stems $\leq 2.5 \mathrm{~cm}$ at the base are gnawed into two or more sections at or near ground level

- trees may tilt at an angle, be easily pulled from ground, or turn brown in the summer due to cut stems or roots

- plugged holes may remain if entire seedling is removed

- roots may be exposed by burrowing

- occurs year-round but more common in winter

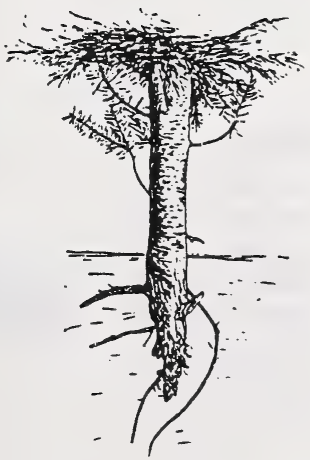

Figure 80 Root clipping. 


\section{FIELD SIGNS}

\section{Tracks}
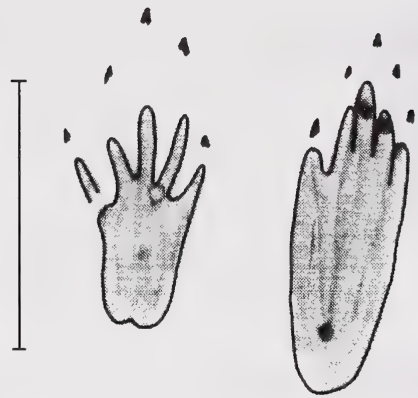

Figure 81 Both front and hind feet have claw marks extending beyond the five toes. Prints are rarely observed in the freshly moved soil of mounds, but may be seen in snow as a waddling gait with a drag imprint of a thick tail. Scale is $2.5 \mathrm{~cm}$.

\section{Scat}

- defecation occurs within the underground tunnel system

- rarely found

\section{Other}

- flat, fan-shaped mounds of soil

- dispersed underground burrow systems

- underground tunnels $5 \mathrm{~cm}$ in diameter

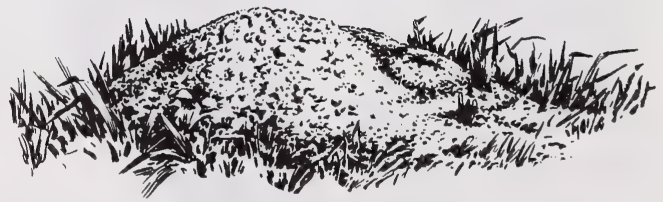

Figure 82 Fan-shaped mounds. 
- earthen winter casts lying on snow in the early spring as a result of winter burrowing in snow

- roots exposed by burrowing

- small seedlings buried in mounds or winter casts

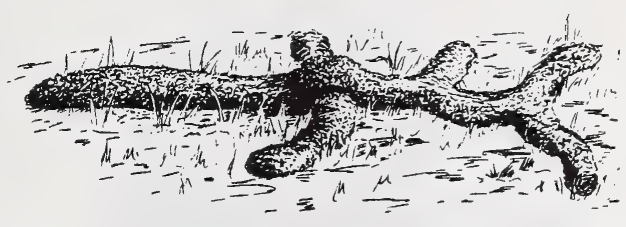

Figure 83 Winter casts.

\section{DISTRIBUTION}

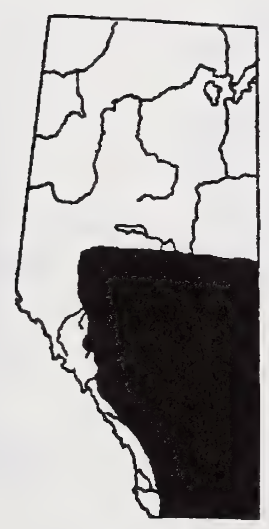

Figure 84 Pocket gopher. 


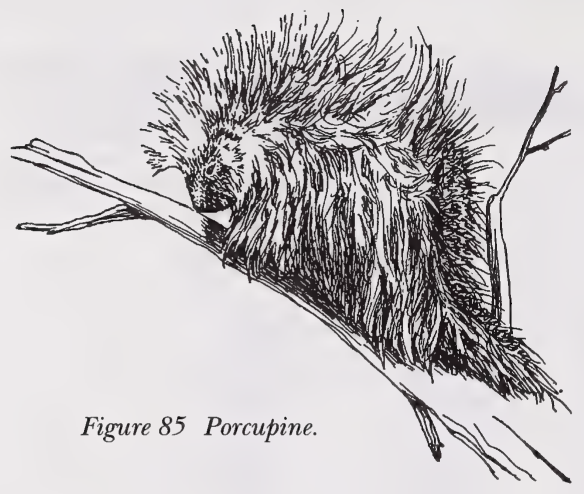

\section{PORCUPINE}

(Erethizon dorsatum)

\section{DAMAGE CHARACTERISTICS}

\section{Bark Damage}

- trembling aspen, balsam poplar, paper birch, willow, and lodgepole pine preferred

- stem girdling on seedlings and polesized trees

- basal, bole, and upper branch gnawing

- distinct broad horizontal or diagonal front tooth marks ( $4.5 \mathrm{~mm}$ wide) in exposed sapwood

- injuries common to areas of the tree accessible from a limb on which the animal can sit

- animals often return to the same injured tree year after year where the callus tissue is also consumed

- occurs in fall and winter

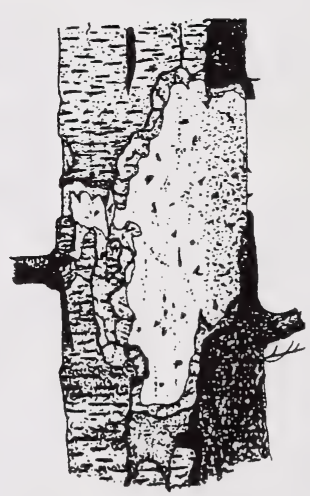

Figure 86 Bark damage.

\section{Clipping / Cutting}

- trembling aspen, balsam poplar, paper birch, willow, and lodgepole pine preferred

- fine twigs are clipped cleanly, at an oblique angle

- larger branches $\leq 2.5 \mathrm{~cm}$ have a slanted cut with a number of parallel rows of tooth marks 


\section{FIELD SIGNS}

Tracks

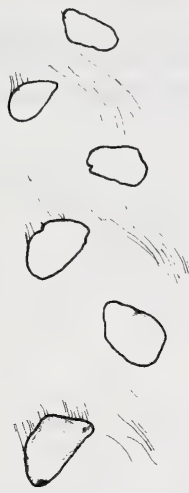

\section{Scat}
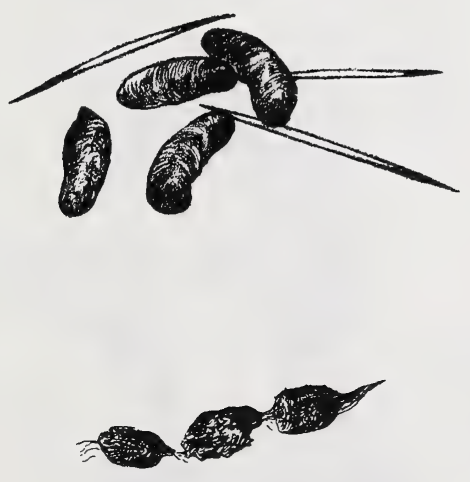

Figure 87 The trail shows a short, waddling gait with pigeon-toed prints. The front foot has four toes and is $6.4 \mathrm{~cm}$ long, including claw marks; the hind foot has five toes and is over $7.6 \mathrm{~cm}$ long, usually printing ahead of the front foot. Clear prints will show the rough texture of the sole of the foot and drag imprints from the hair on the lower legs. A drag mark from the tail is common and even the body in deep snow. Lines drawn through the long axis of each print forms an arrow indicating the direction of travel.

Figure 88 In winter, conifer-containing pellets are elongated ( $25 \mathrm{~mm}$ long), often curved and yellow or red. Quills may be found among the scat.

Figure 89 In summer, scat containing grasses, herbs, and shrubs are black and individual segments may be joined together by thin strands.

\section{DISTRIBUTION}

- porcupine are distributed throughout Alberta 


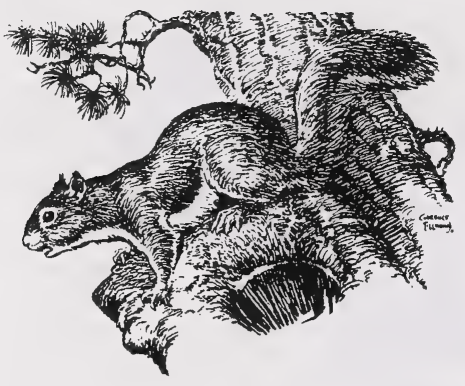

Figure 90 Red squirrel.

\section{RED SQUIRREL}

(Tamiasciurus hudsonicus)

\section{DAMAGE CHARACTERISTICS \\ Bark Damage}

- mature conifers $>6 \mathrm{~cm}$ diameter preferred

- $1 \mathrm{~cm}$ wide bark strips removed vertically or diagonally from upper bole or branches in either irregular or circular patches that leave ragged edges

- girdling may occur 1.8 - 4.6 m from the crown

- prominent tooth marks lacking as squirrels commonly lick exposed sapwood

- fine gnawing may be visible on the sapwood with marks $1.6-2.5 \mathrm{~mm}$ wide

- discarded outer bark (2.5 x $7.5 \mathrm{~cm}$ ) found on the ground beneath injured trees will differentiate this barking damage from that of porcupine

- bark may be left hanging from tree, but phloem and cambium underneath are consumed

- damage usually occurs in late spring and early summer with rare occurrences in late summer

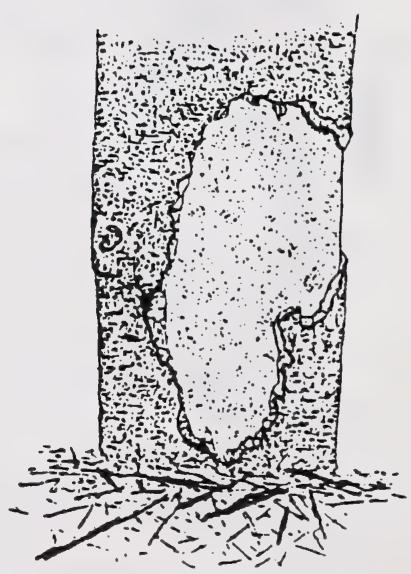

Figure 91 Bark damage from red squirrel. 


\section{Clipping / Cutting}

- slanted cutting of terminal and lateral conifer twigs and branches

- cutting creates a rough edge with tooth marks that rasp rather than gouge like other rodents or hares

- cuts may appear smooth and square-like due to exuded resin

- green branchlets lying on the ground, often with cones or buds removed

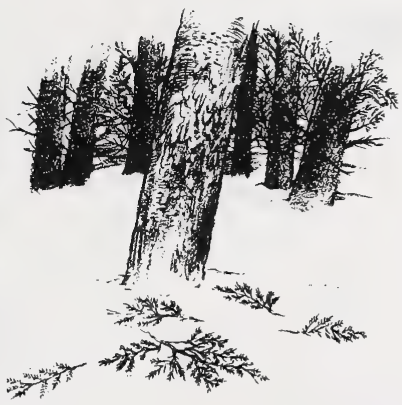

Figure 92 Branchlets clipped with cones removed.

\section{Cone Damage}

- green, unopened conifer cones or small twigs litter the ground

- oblique cuts on branchlet ends with a rough edge

- cone cutting occurs in late summer with ripening of cones

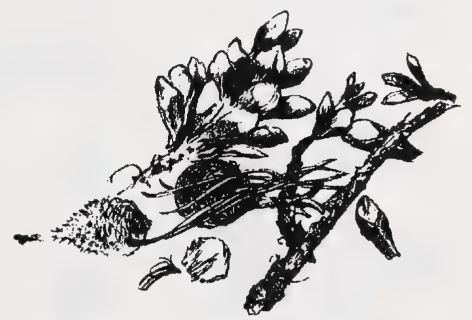

Figure 93 Cones and twigs on the ground.

\section{FIELD SIGNS}

\section{Tracks}

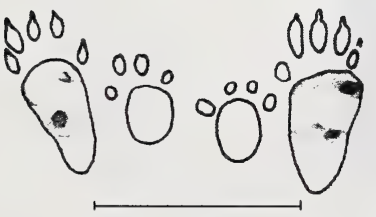

Figure 94 Pads may show without the outline of the foot. The hind foot has five toes and the front foot has four toes. Tracks may end at the base of a tree. Scale is $5 \mathrm{~cm}$.

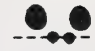

1. Figure 95 The gait of tree dwelling squirrels shows paired

-2- front feet hopping perpendicular to the line of travel. 


\section{Scat}

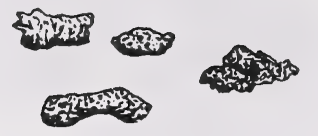

Figure 96 Individual scats are often irregular and may range from spherical to ellipsoid $(8 \mathrm{~mm}$ long). Scat are found on logs, stumps, middens, and in squirrel nests. When the diet is moist, pellets will form small clumps.

\section{Other}

- middens (accumulations of cone scales and stalks indicative of feeding stations)

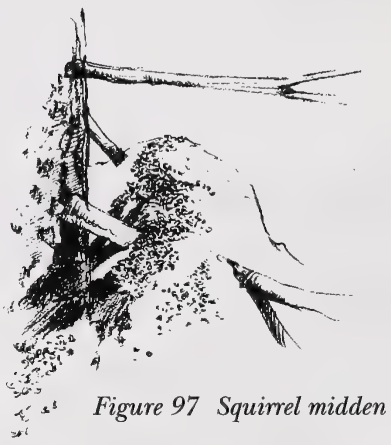

\section{DISTRIBUTION}

Figure 98 Red squirrel.

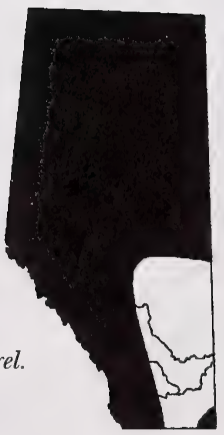




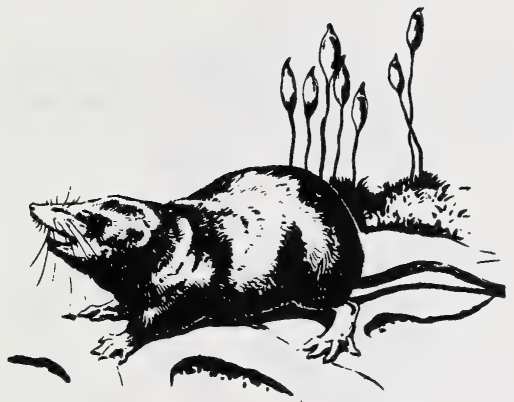

\section{SHREW}

(Sorex spp.)

Figure 99 Shrew.

\section{DAMAGE CHARACTERISTICS}

\section{Seed Losses}

- seeds are split almost in half, as opposed to mice and chipmunk damage

- seeds shattered with very irregular edges rather than gnawing at seed edges only as in mice or removal of one-half of the flat seed surface as in chipmunks

\section{FIELD SIGNS}

\section{Tracks}
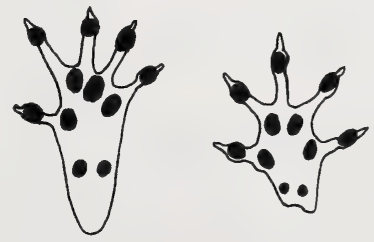

Figure 101 Five toes are present on both feet. Often only the pads will show in a track; in a clear print, however, the overall outline may register. Scale is $2.5 \mathrm{~cm}$.

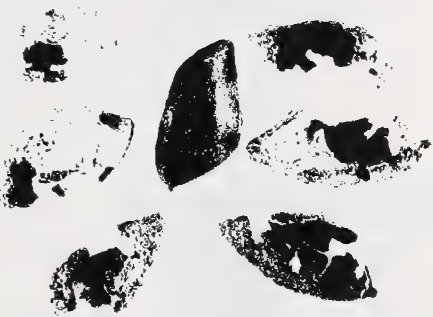

Figure 100 Seed damage by a shrew.

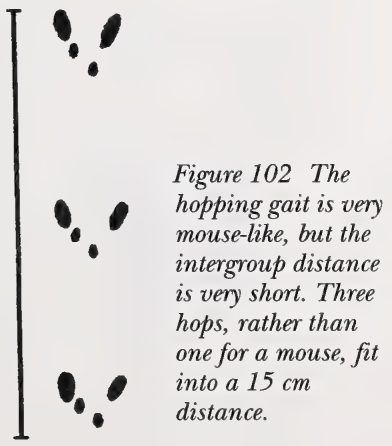




\section{Scat}

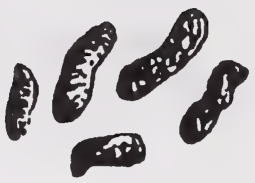

Figure 103 Scats are cylindrical and $0.64 \mathrm{~cm}$ long. They can only be distinguished from mice or vole droppings by the presence of other sign.

\section{Other}

- burrow openings $\leq 2.5 \mathrm{~cm}$ in diameter, which are smaller than those of voles or mice

- nest 15-20 cm in diameter along a tunnel

- droppings located outside the nest, as opposed to mice

\section{DISTRIBUTION}

- 7 shrew species are distributed throughout Alberta

- for detailed species maps see

Pattie and Hoffman 1992 


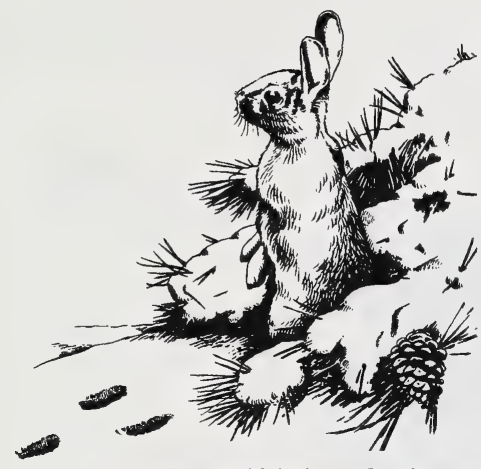

\section{SNOWSHOE HARE}

(Lepus americanus)

Figure 104 Snowshoe hare.

\section{DAMAGE CHARACTERISTICS}

\section{Bark Damage}

- pine preferred over spruce and trembling aspen and willow are preferred over balsam poplar, alder, and buffaloberry

- barked stems usually $\leq 6 \mathrm{~cm}$ diameter

- bark removed from base of coniferous and deciduous trees up to $2 \mathrm{~m}$ high (varies with snow depth)

- gnawing in patches typical, but patches may be joined into long strips or to girdle the stem

- sapwood appears ragged with $2 \mathrm{~mm}$ wide horizontal or diagonal tooth marks

- individual tooth marks not always distinct

- occurs from fall through spring

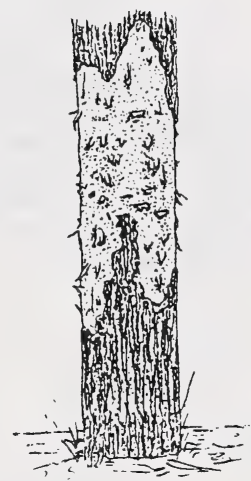

Figure 105 Bark damage caused by snowshoe hare.

\section{Clipping}

- clip branches, stems, and buds of coniferous and deciduous trees at a $45^{\circ}$ angle

- stems $\leq 6 \mathrm{~mm}$ in diameter preferred

- height of damage above ground varies with snowdepth

- can reach up to $0.5 \mathrm{~m}$ above snow

- occurs from fall through spring

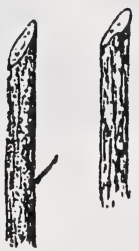

Figure 106 Seedlings clipped by snowshoe hare. 


\section{FIELD SIGNS}

\section{Tracks}

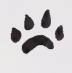

10

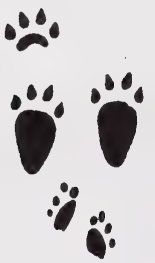

Figure 107 Tracks as the gait changes from a hop to a walk. Heelprints are not apparent when the hare walks on its toes. Five toes are present on the front foot and four on the hind foot. The fifth digit and other toes may not register due to hair on the feet. Scale is $5 \mathrm{~cm}$.

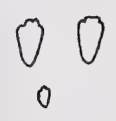

0

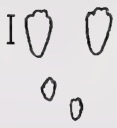

Figure 108 The diagonal hop of the snowshoe hare. The hind feet are exceptionally wide. Scale is $5 \mathrm{~cm}$.

\section{Scat}

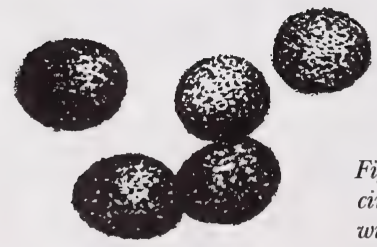

Figure 109 Scats are slightly flattened and circular (1.3 cm in diameter). Scat is brown in winter and more greenish in summer. When the pellets are broken open the woody content is observed and they may have a sweet smell. Scats may be deposited singly or in small piles. 


\section{Other}

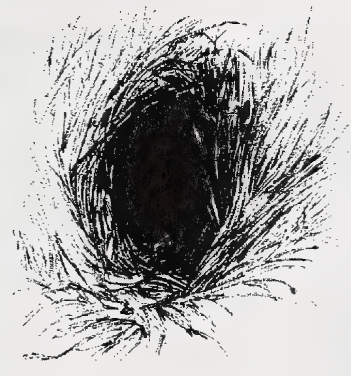

Figure 110 Trails occur in tall grass and underbrush where a tunnel may form through overarching grass blades and twigs, respectively. Well-traveled trails, $10-15 \mathrm{~cm}$ wide, may contain scat.

\section{DISTRIBUTION}

Figure 111 Snowshoe hare.

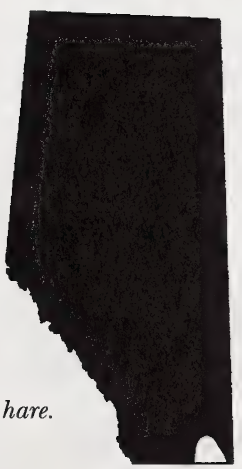




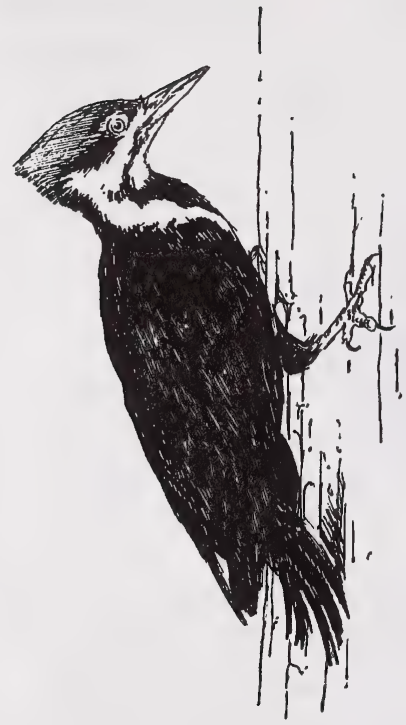

\section{Woodpecker PILEATED WOODPECKER}

(Dryocopus pileatus)

YELLOW-BELLIED SAPSUCKER

(Sphyrapicus varius)

Figure 112 Pileated woodpecker.

\section{DAMAGE CHARACTERISTICS}

\section{Bark Damage}

\section{Pileated Woodpecker}

- occurs on large mature coniferous trees

- damage at base of tree close to ground

- large wood chips at base of tree

- irregular shaped excavated hole

- may be seeking insects

\section{Yellow-bellied Sapsucker}

- birch, aspen, and pine preferred

- damage to saplings and mature trees

- damage on bole at all heights but crown preferred

- series of round $(0.5 \mathrm{~cm})$ holes in regular spaced rows

- feed on sap and insects attracted to sap 


\section{Woodpecker cavities}

- mature deciduous trees and partly alive trees preferred

- round or oval shaped entrance leads to expanded cavity

- cavities may be occupied by other cavity nesting birds or mammals

\section{FIELD SIGNS}

\section{Other}

- large excavated cavities (3-5 cm entrance) on neighboring well rotted snags

- large wood chips at base of snags

\section{DISTRIBUTION}

- woodpeckers are distributed throughout the forested areas of Alberta

Figure 113 Pileated woodpecker and yellow-bellied sapsucker.
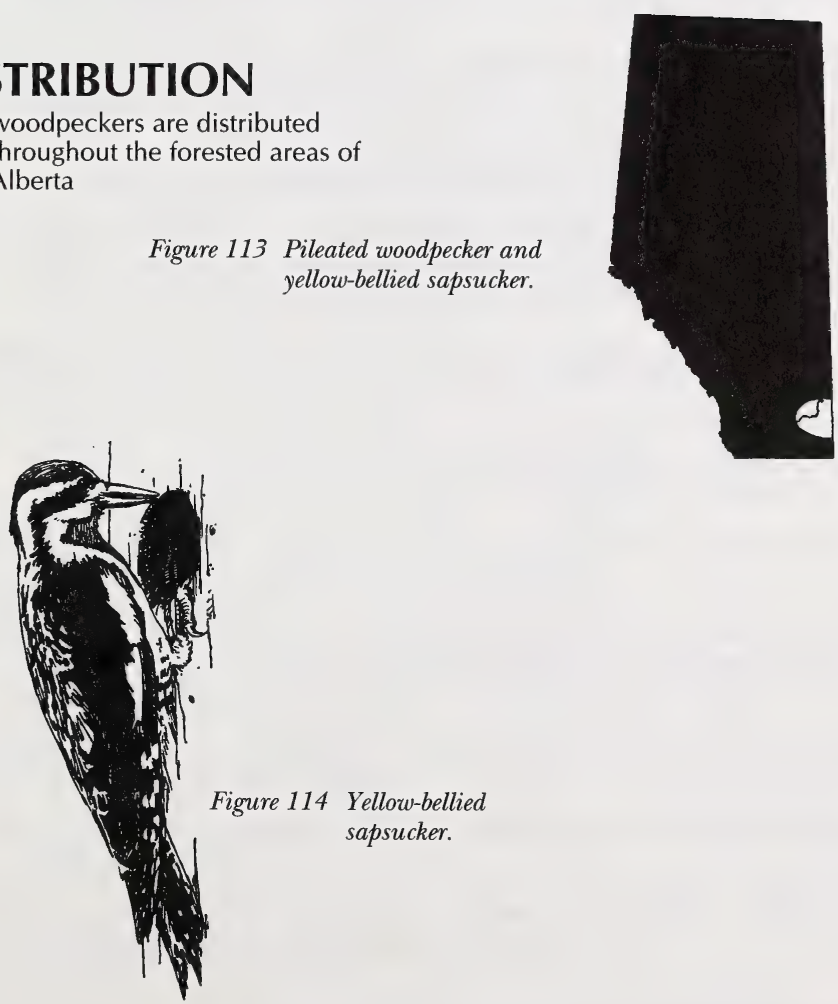



\section{REFERENCES}

Anonymous. 1984. Alberta conservation and hunter education. Alberta

Energy and Natural Resources Fish and Wildlife Division Reference

NO. 10. Edmonton, Alberta

Barnes, V.G., Jr. 1973. Pocket gophers and reforestation in the Pacific

Northwest: a problem analysis. Fish and Wildlife Service Bureau of

Sport Fisheries and Wildlife Special Scientific Report. Wildlife No.

155. Washington. D.C. 18 pp.

Eadie, W.R. 1954. Animal control in field, farm and forest. MacMillan Co.,

New York, New York 257 pp.

Halfpenny, J. and E. Biesiot. 1986. A field guide to mammal tracking in North America. 2nd ed. Johnson Books, Colorado. 164 pp.

Harestad, A.S., F.L. Bunnell, T.P. Sullivan, and L. Andrusiak. 1986. Key to injury of conifer trees by wildlife in British Columbia. Resource Branch, Ministry of Forests. WHR-23. Victoria, British Columbia 38 pp.

Harper, P.A., and A.S. Harestad. 1986. Vole damage to coniferous trees on Texada Island. The Forestry Chronicle 62:429-432.

Jackson, J.J. 1991. Controlling vertebrate animal damage in southern pines. Pages 421-426 in M.L. Duryea and P.M. Dougherty, Editors. Forest regeneration manual. Kluwer Academic Publishers, London.

Johnsgard, P.A. 1973 Grouse and quail of North America. University of Nebraska Press, Lincoln, Nebraska. 553 pp.

Lawrence, W.H., N.B. Kverno and H.D. Hartwell. 1961. Guide to wildlife feeding injuries on conifers in the Pacific Northwest. Western Forestry and Conservation Association. Portland, Oregon. 44 pp.

Mitchell, G.E. 1950. Wildlife-forest relationships in the Pacific Northwest region. Journal of Forestry 48:26-30.

Murie, O.J. 1975. A field guide to animal tracks. 2nd ed. Houghton Mifflin, Boston. 375 pp.

Pattie, D.L. and R.S. Hoffman. 1992. Mammals of the North American parks and prairies. Edmonton, Alberta. 579 pp. 
Pearce, J. 1947. Identifying injury by wildlife to trees and shrubs in northeastern forests. USDI Fish and Wildlife Service, Washington. D.C. Resource Report 13. 29 pp.

Pigott, C.D. 1985. Selective damage to tree-seedlings by bank voles. Oecologia. $67: 367-371$.

Radvanyi, A. 1971. Lodgepole pine seed depredation by small mammals in western Alberta. Forestry Science 17:213-217.

Schwartz, C.W., and E.R. Schwartz, Editors. 1981. The wild mammals of Missouri. University of Missouri Press, Columbia. 356 pp.

Scott, J.D. and T.W. Townsend. 1985. Characteristics of deer damage to commercial industries of Ohio. Wildlife Society Bulletin 13:135-143.

Stelfox, J.B. Editor. Hoofed mammals of Alberta: their ecology, status, and management. Lone Pine Press, Edmonton. 284 pp.

Stokes, D.W., and L.Q. Stokes. 1986. A guide to animal tracking and behavior. Little, Brown and Company, Boston, Maryland, $418 \mathrm{pp}$.

Sullivan, T.P., J.A. Krebs, and H.A. Kluge. 1987. Survey of mammal damage to tree fruit orchards in the Okanagan Valley of British Columbia. Northwest Science. 61:23-31.

Timm, R.M. Editor. 1983. Prevention and control of wildlife damage. Great Plains Agriculture Council Wildlife Resources Committee and Nebraska Cooperative Extension Services, Institute of Agriculture and Natural Resources, University of Nebraska, Lincoln.

Whitaker, J.O., Jr., R. Elman, and C. Hehring. 1980. The Audubon Society field guide to North American mammals. Alfred A. Knopf, New York. $745 \mathrm{pp}$. 





\section{Bibliothèque nationale du Canada}

33286513468047 